\author{
الويتبندى و ارزيابى نقشه يّانسيل منابع آب زيرزمينى در استان اصفهان$$
\text { مسيح مرادىزاده' و كورش شيرانى }
$$

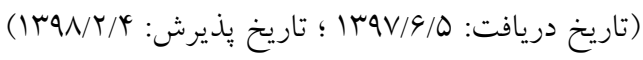

جكيده

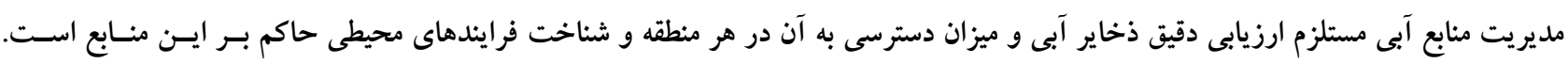

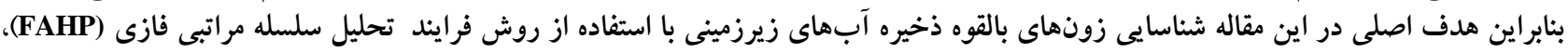

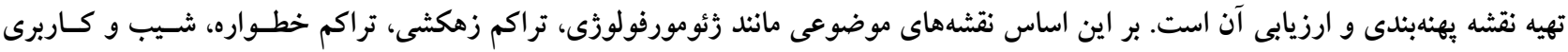

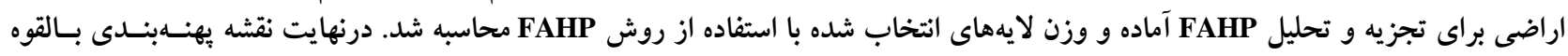

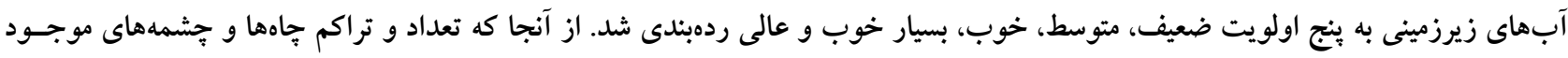

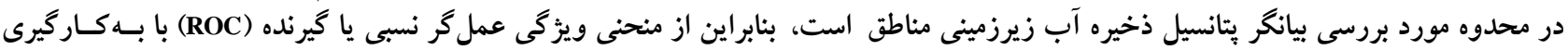

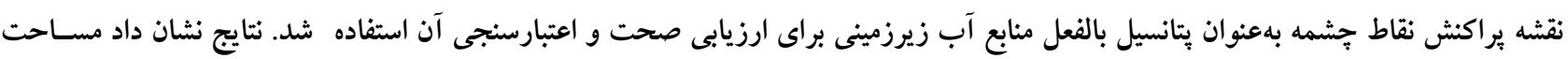

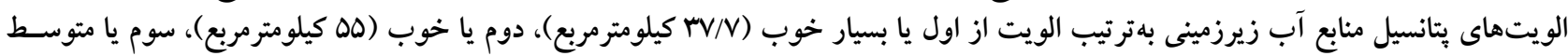

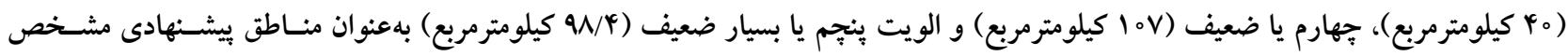

وازمهاى كليدى: ارزيابى، يُهنهبندى، آب زيرزمينى، وزندهى، FAHP

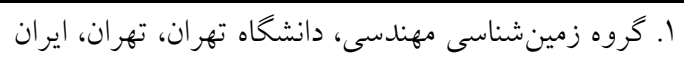

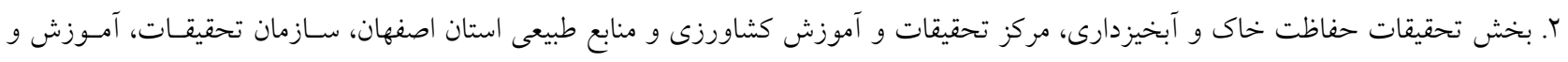

$$
\text { ترويج كشاورزى، اصفهان، ايران }
$$

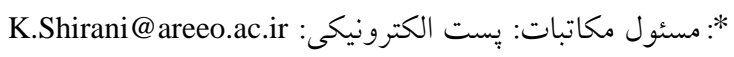




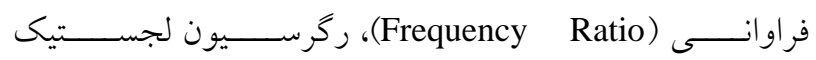

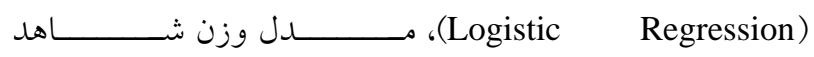
و آنتروي (Weights-of-Evidence) (Shannon’s Entropy) تكنيكهــاى محاسـبات نرم|فـزارى ماننــــ درخــت تصــميم (Decision Tree) (IN) (Artificial Neural Network) تهيه نقشه مناطق بالقوه آب زيرزمينى استفاده شده است.

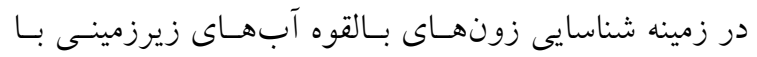

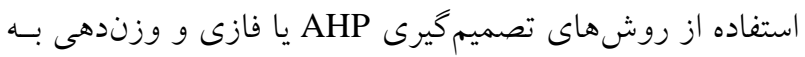

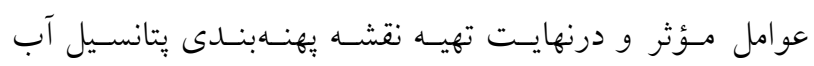
زيرزمينى نيز يزوهش هاى مختلفى همر اه با نتايج مفيـدى انجـام

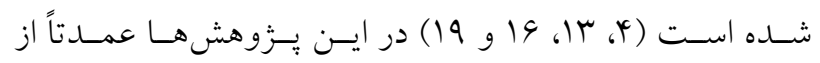

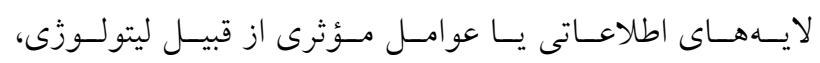

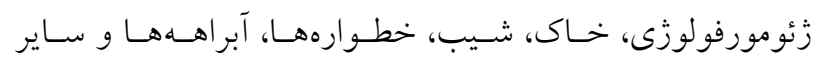

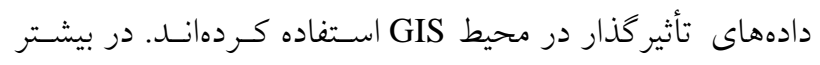

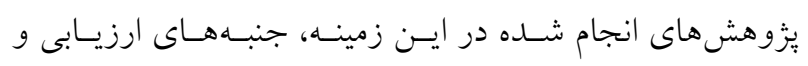

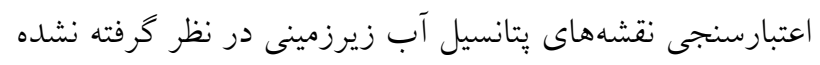

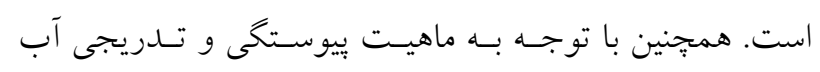

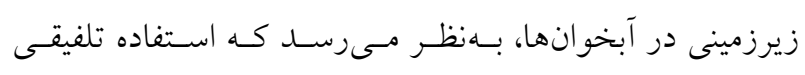

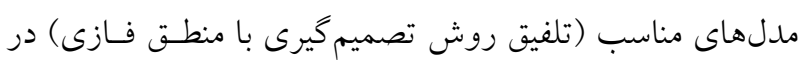

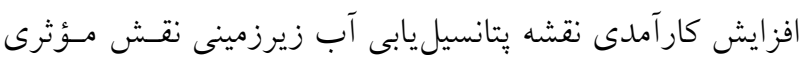

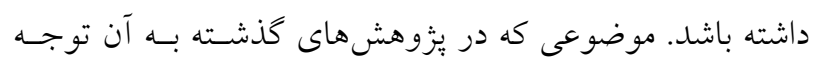

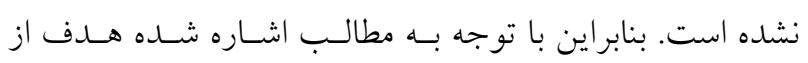

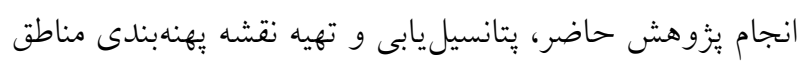

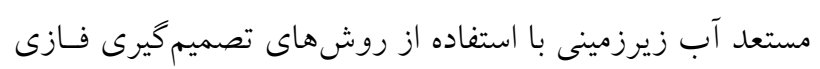

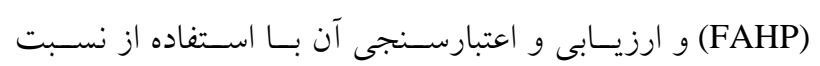

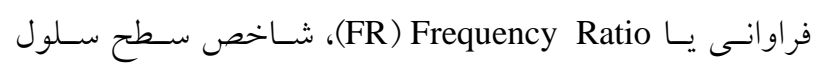

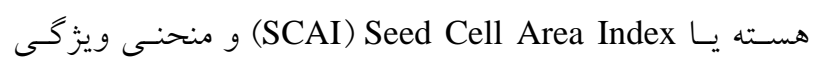
عملكر كيرنده يا (ROC) Recievier Operating Charactristic است. لازم بهذكر است جنبه نوآورانه اين بُزوهش بــــــاركيرى

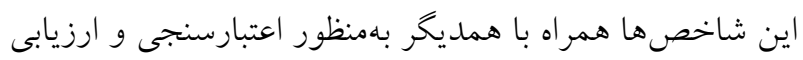

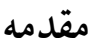

آبهاى زيرزمينى، منابع تجديدنايذير طبيعى زمسين هستـند كـهـ

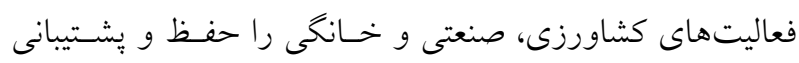

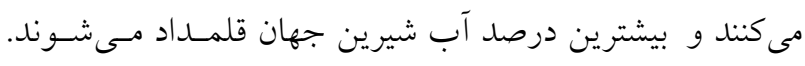

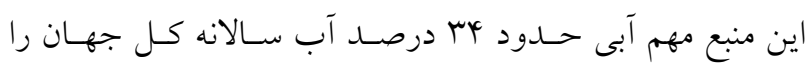

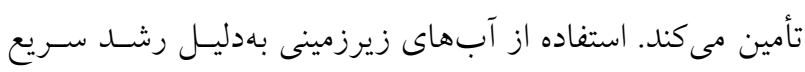

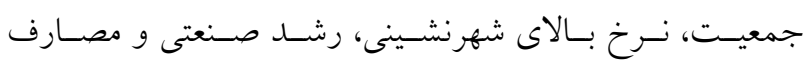

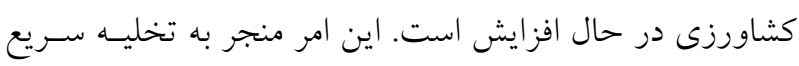

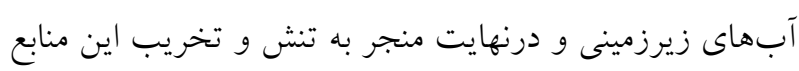

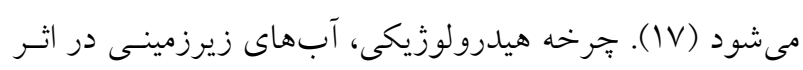

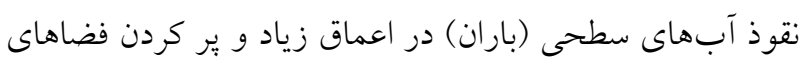

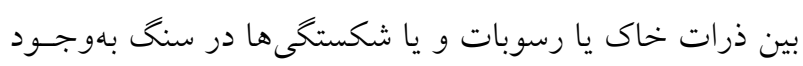

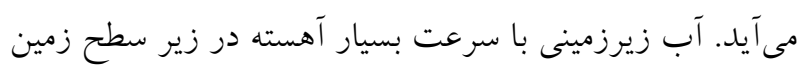

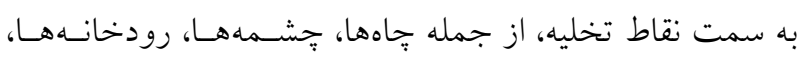

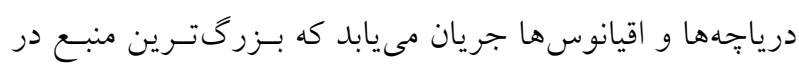

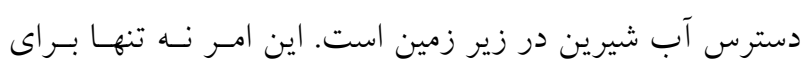

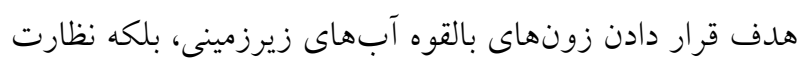

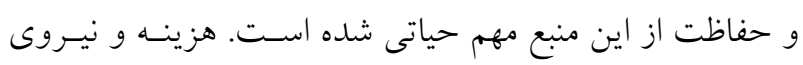

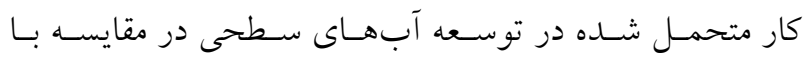

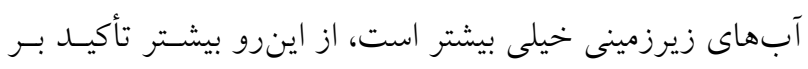

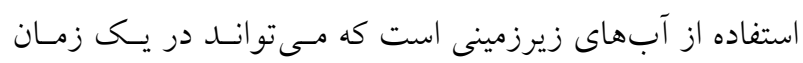

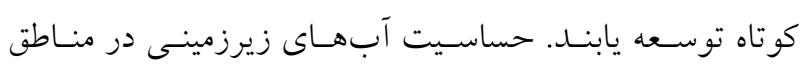

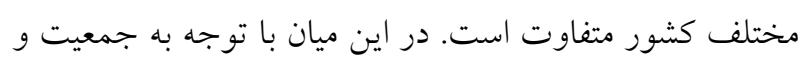

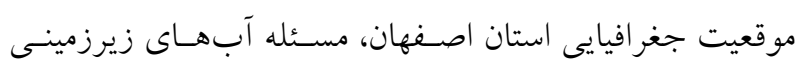

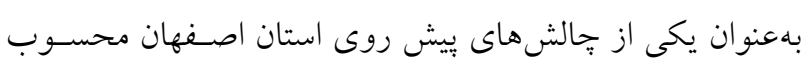

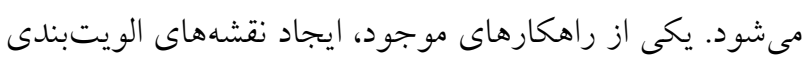

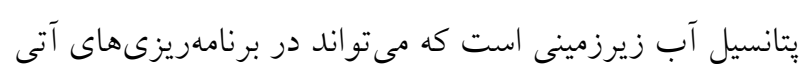

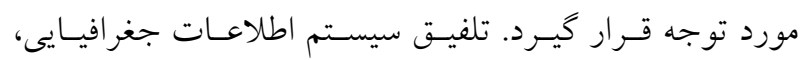

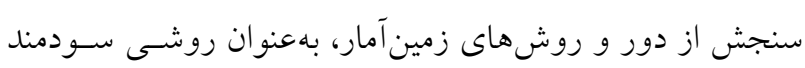

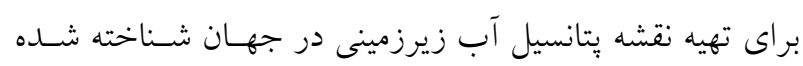

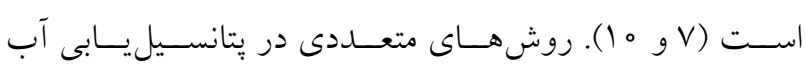

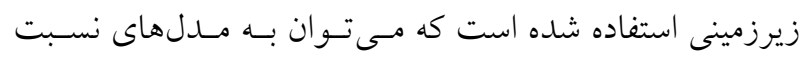




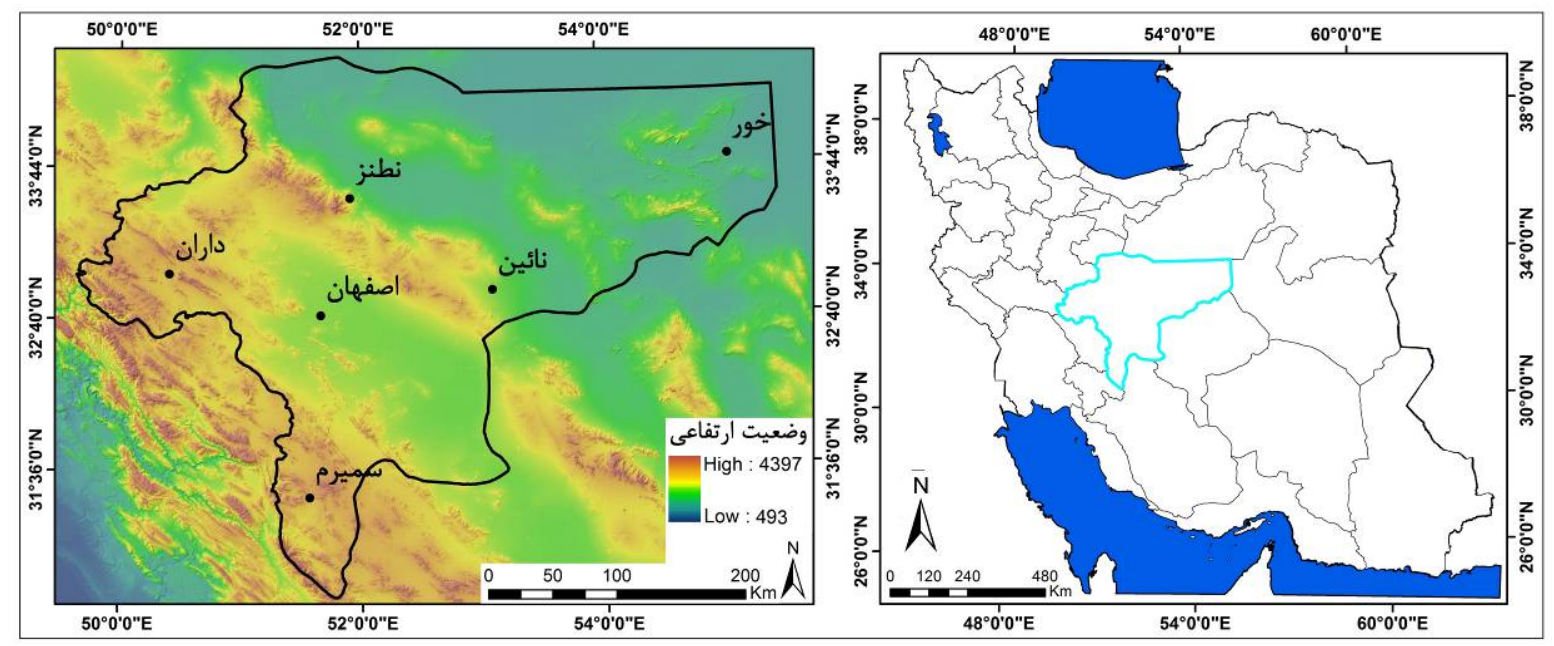

شكل 1. موقعيت منطقه مورد مطالعه

كزارش سازمان هواشناسى استان اصفهان و با توجه به آمـار هQ ساله اخير (0ها| تا هوس|)، بيشينه درجه حرارت

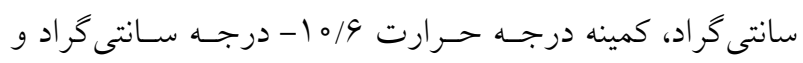
متوسط درجه حرارت سالانه /9/V ادرجه سانتى گراد ثبـت شـده

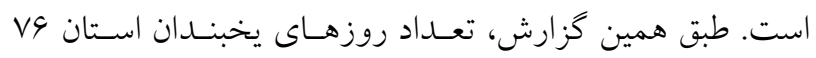
روز و متوسط ميزان بارندكى سـالانه آن 19/9 ميلىمتـر اسـت

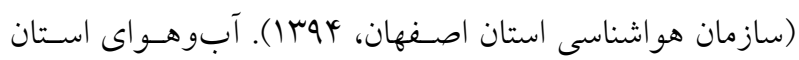
اصفهان بهطور كلى معتلدل خشك است، اما بـا توجسه بـهـ تـأثير بادها و دورى و نزديكى به منطقـه كوهستانى غـرب و دشـت كوير در شرق و جنـوب شـرقى، آبوهــواى آن در سـه بخـش

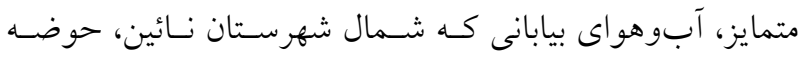

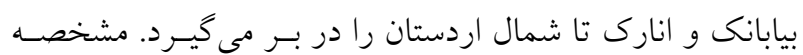
ويزه آن تغيير شديد و سريع درجه حرارت، كمى بارش باران و وزش بادهاى تند در طول سال است. آبوهواى نيمهبيابانى كـه

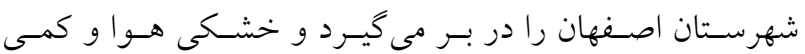

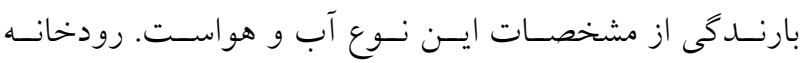
زايندهرود به طرز جشم گيرى روى آبوهواى اين ناحيـه تـأثير مثبت دارد و آن را تعديل مى كند و آبوهواى نيمهمرطوب سرد كه قلمرو غرب و جنوب غربى اصـفهان را در بـر مى گيسرد. بـه نسبت افزايش ارتفاع، ميزان بارندكى افزايش مى يابد و از درجه كرماى هوا نيز كاسته مىشود.
مدل و تعيين آستانهاى مناسب براى طبقات نقشه الويتبنـدى

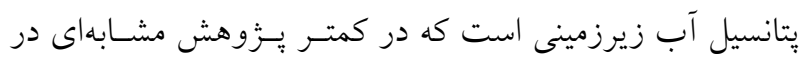
زمينه تهيه نقشههاى يتانسيل يابى آب زيرزمينى بـكار كرفته شده است.

\section{مواد و روشها}

منطقه مورد مطالعه

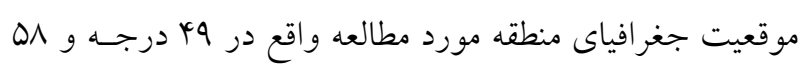

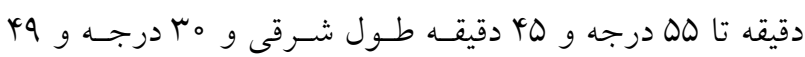

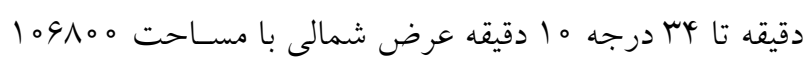
كيلومتر مربع است (شكل (). با توجـهـ بـهـ قرارگيـرى در مركـز فلات ايران از نظر مورفوتكتونيكى شامل جهار واحد ساختمانى

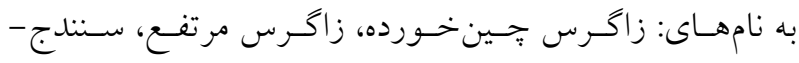
سيرجان و ايران مركزى است. از جمله گسلهاى اصلى منطقـه، مىتوان به گسل درونه، گسل دهشيربافت، گسل زاخرس، گسل يشت بادام، كسل قم - زفره و كسل كاشان اشـاره كـرد (IV). از نظر اقليمى نيز بهدليل واقع شدن در مركز ايران و در دامنـههاى شرقى سلسله جبال زاگرس موجب شده است تا هماننـد سـاير مناطق مركزى كشور بهدليل تغييرات آبوهوايى در اين منـاطق

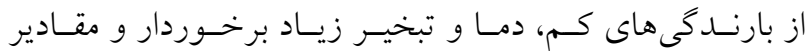
بارندگى آن نيز همواره دجّار نوسانات شديد باشـــ. بـر اسـاس 


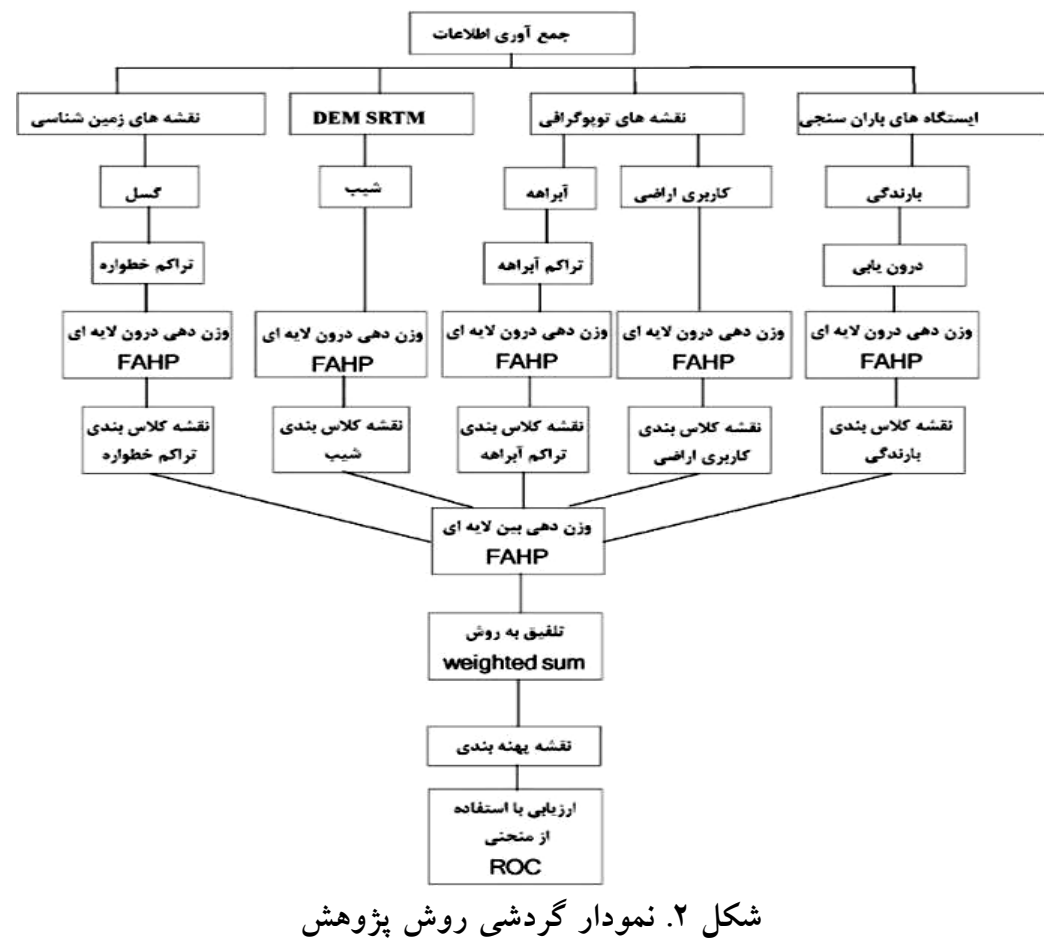

كنترل عواملى مانند سيلخيزى، نفوذيذيرى، تشكيل خاك داشته مواد و روش ها

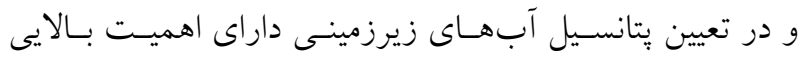

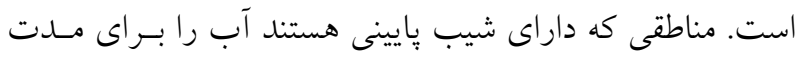

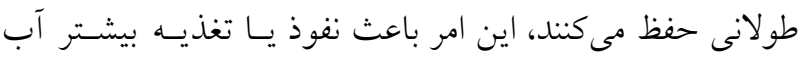

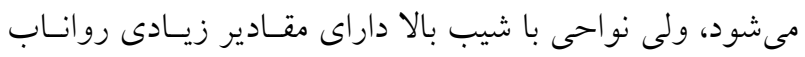

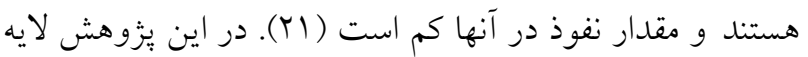

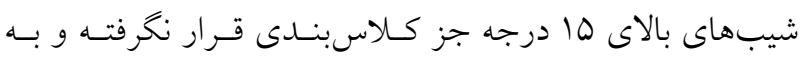

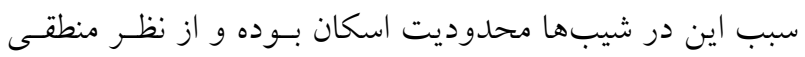
شامل ارزشدهى نيست و در نتيجه اين محسدوده ماسـى شـده

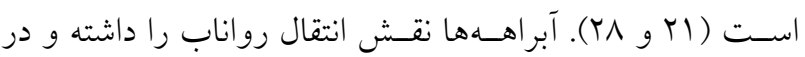

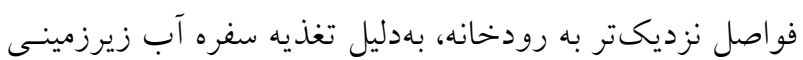

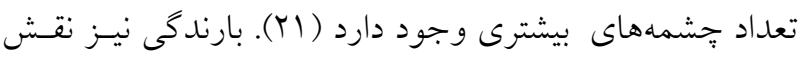

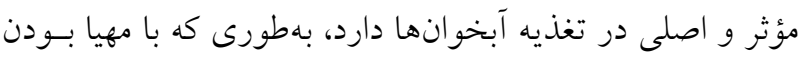
حالت ايدهآل تمامى معيارهاى مؤثر، اخر بارندگى اتفــاق نيافتـد،

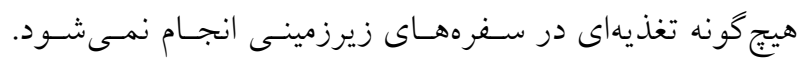

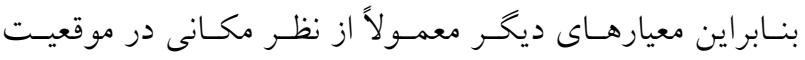

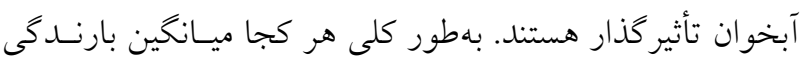
دادهها و آمادهازى معيارهاى تأثير گذار بر آب زيرزمينى

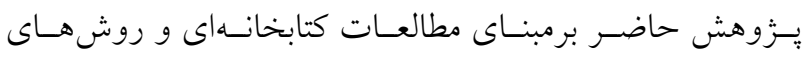

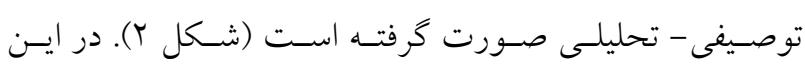
يزّوهش از دادههاى اطلاعاتى مختلف شامل تصاوير مـاهوارهاى

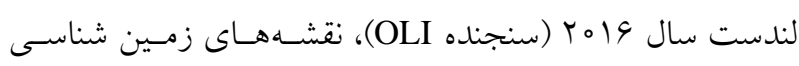

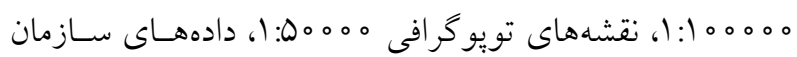
هو اشناسى و همجِنين DEM مت متر SRTM استفاده شده است.

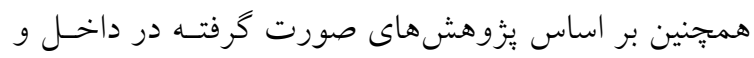

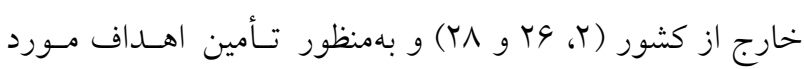

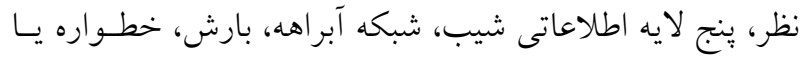

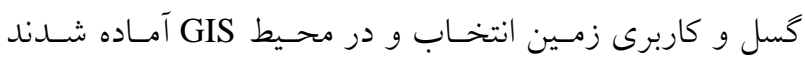

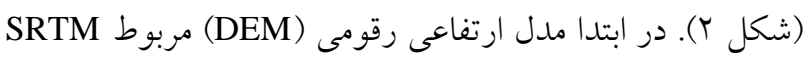

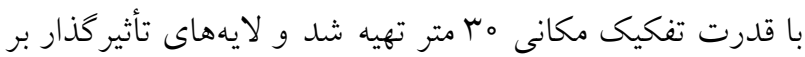

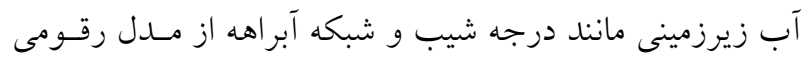

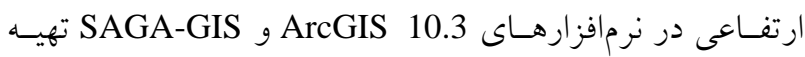

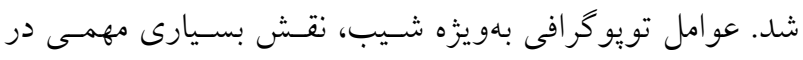




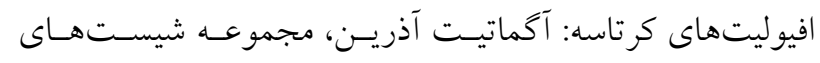

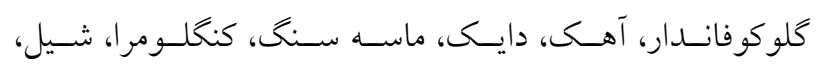

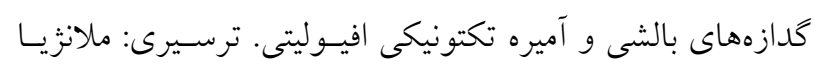

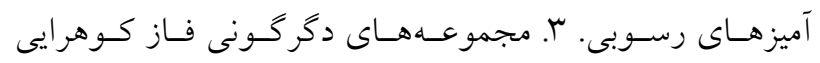

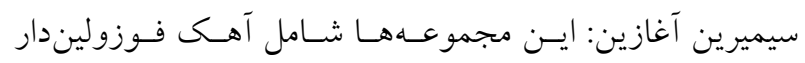

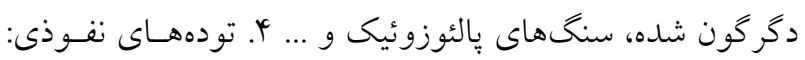

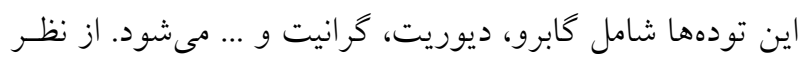

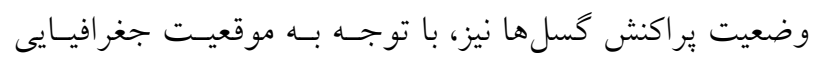

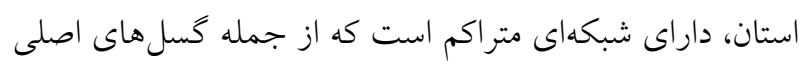

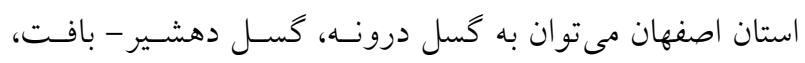

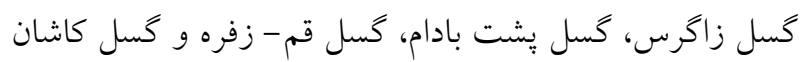

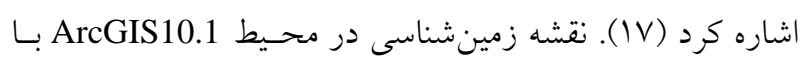

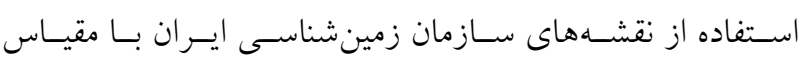
1 1:00000

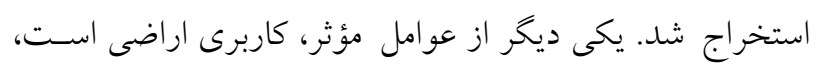

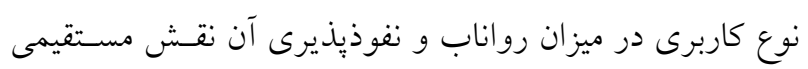

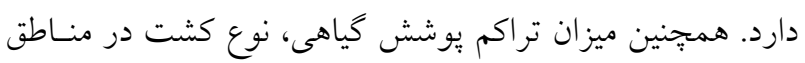

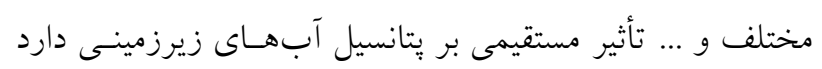

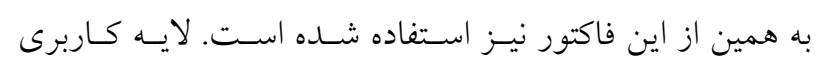

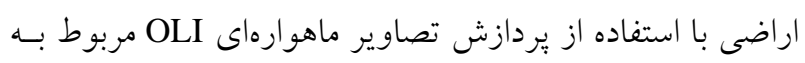

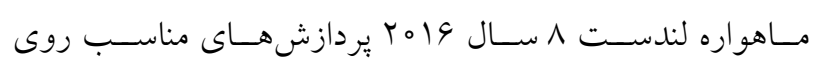

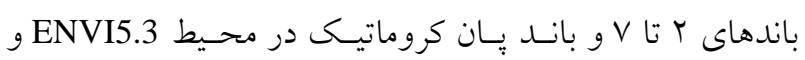

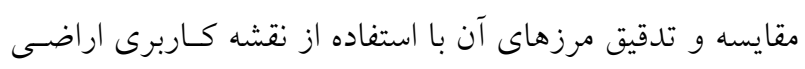

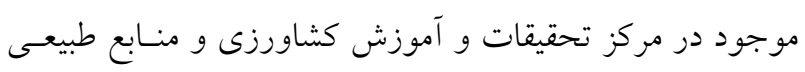

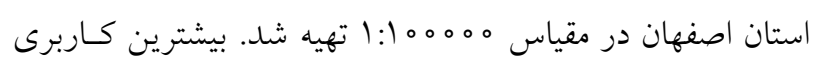
منطقه مورد مطالعه، مرتع و رخنمونهاى سنكى است. معيارهاى

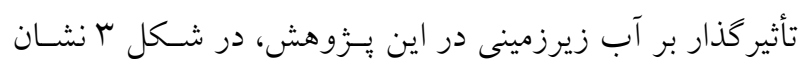

$$
\text { داده شده است. }
$$

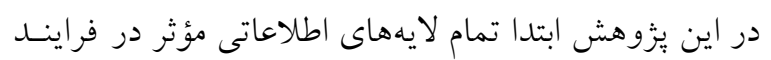
مدل تهيه شده و سبس نقشههاى مورد نظر استخراج شده است.

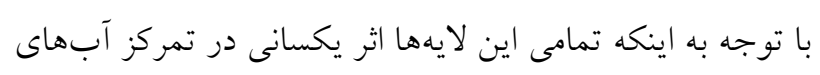

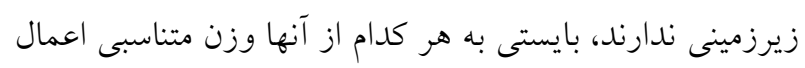

بيشتر باشد، ميزان تغذيه آبخوانها نيز بيشتر اسـت. همجنـين از

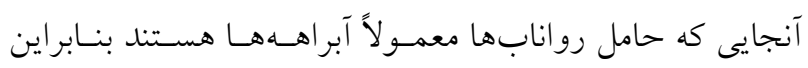

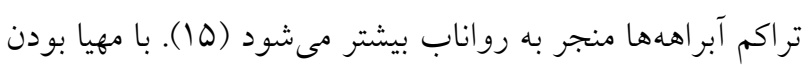

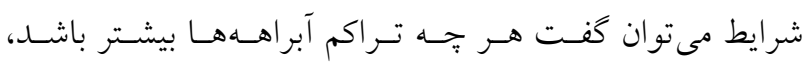

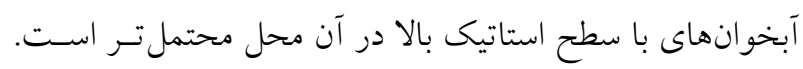

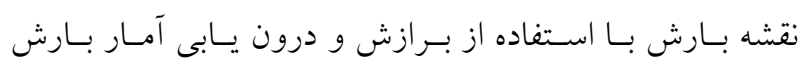

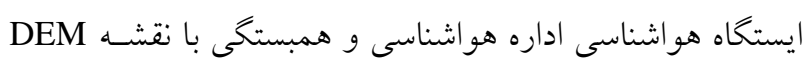
با استفاده نرم افزار ArcGIS10.1 تهيه شداند. نوع سنخششناسى و ويزّكىهـاى وابسته به آن نظير بافت و

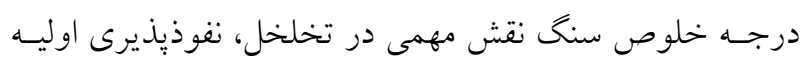

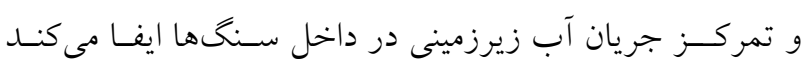

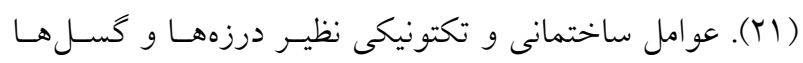

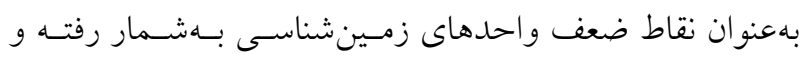

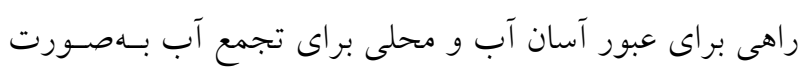

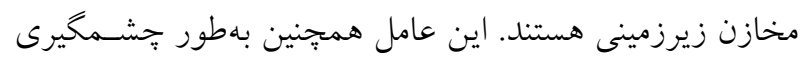

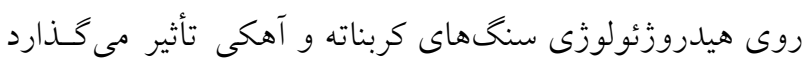

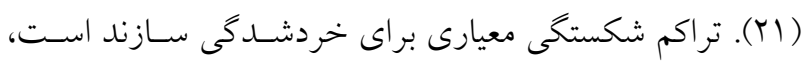
بدين معنى كه تعداد درزه و شكستخى كه بهازاى هر واحد طول در يك منطقه ظاهر مىشوند، مدنظر است. افزايش تـر اكم درزه

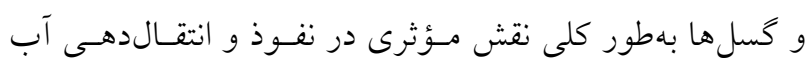

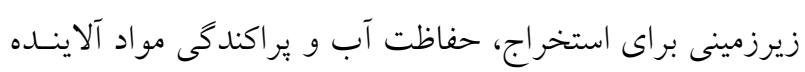

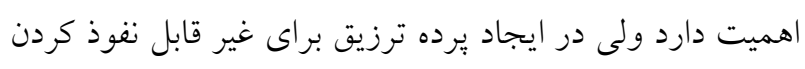

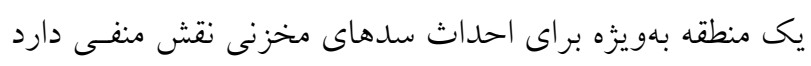

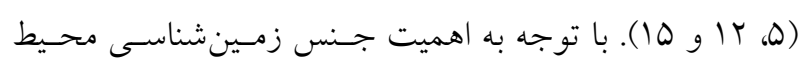

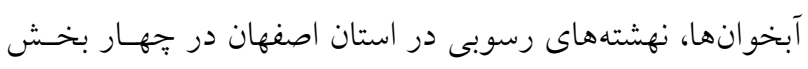

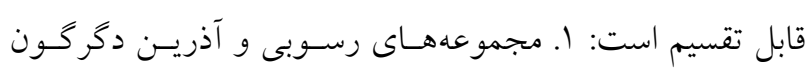

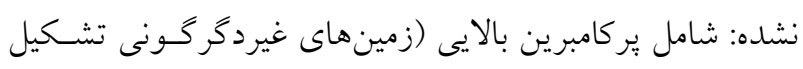

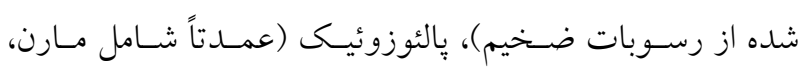

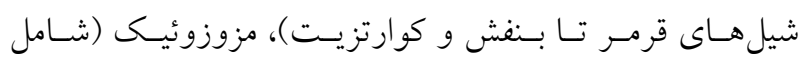
سازندهاى شترى، ناى بند، شمشك و ...)، سنوزوئيك (عمدتاً از

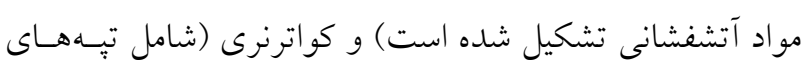

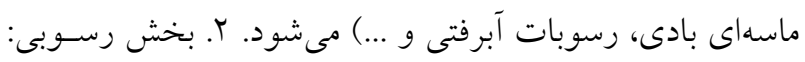



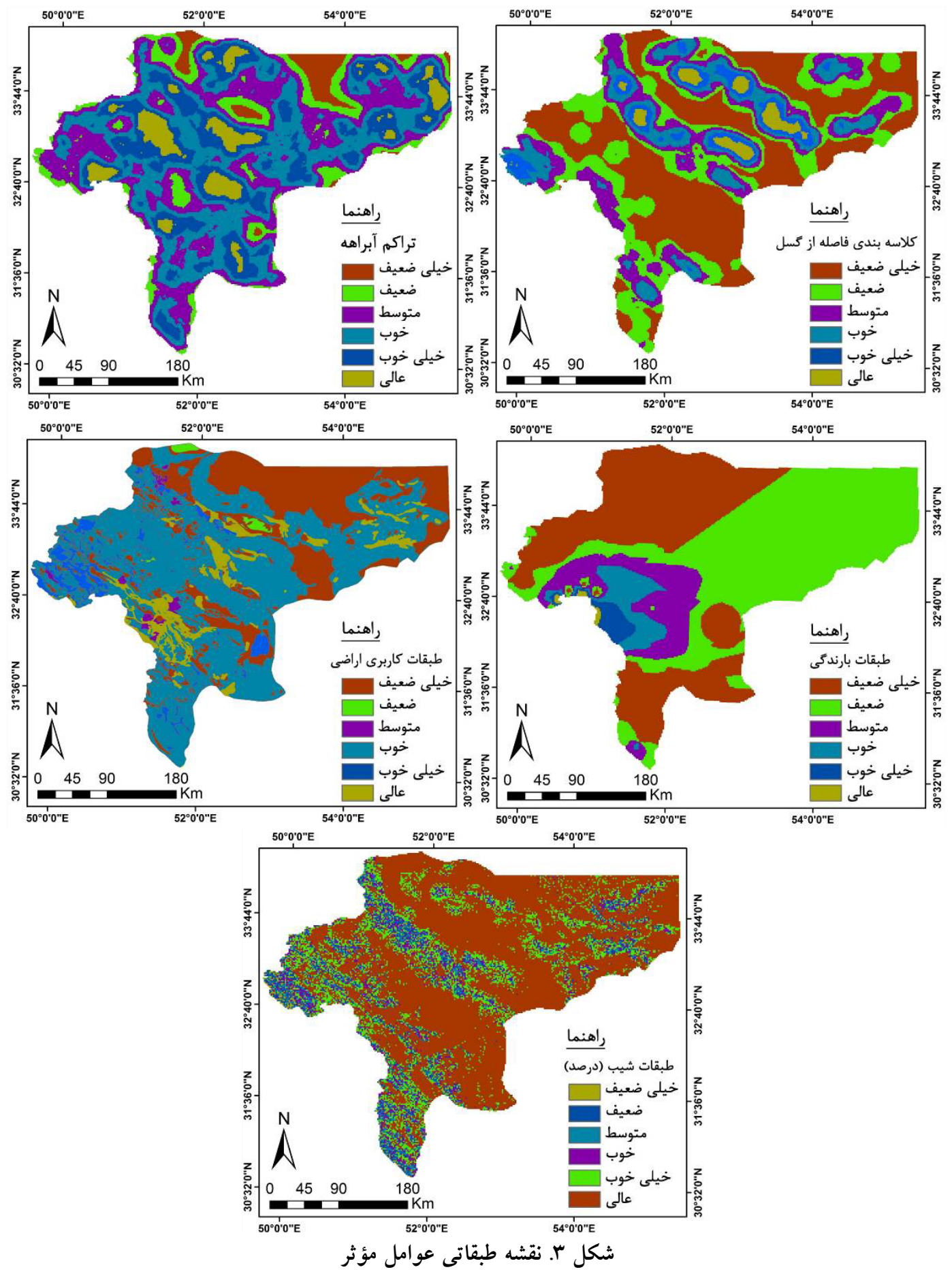

وارد جدول اطلاعاتى لايسهها شـده اسـت (جـدول 1) و مـورد تجزيه و تحليل قرار كرفتـــ. در مرحلـه بعـــ مقـادير وزنسى و و

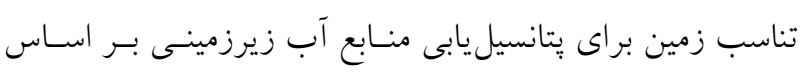
روش FAHP در هر كداميك از لايهها مشخص شد و نقشههاى آنها با دامنه تناسب عالى تا خيلى كم تهيه شدند (شكل ثان).
شود. بهمنظور وزندهى به لايههاى اطلاعساتى از جامعسه آمـارى سب نفره از اساتيد دانشخاه، مهندسين آب منطقهاى و كارشناسان

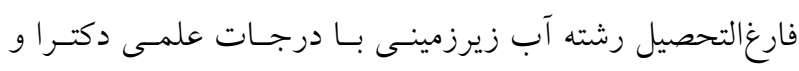

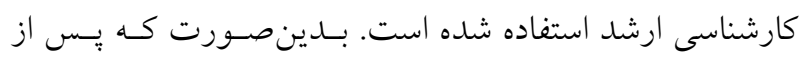

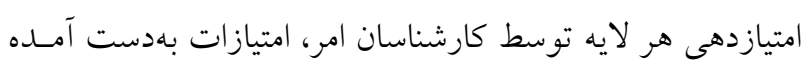


جدول 1. كلاسبندى معيارها و وزنهاى تخصيصيافته به معيارها و زيرمعيارها

\begin{tabular}{|c|c|c|c|c|c|}
\hline وزن كلى & وزن زيرمعيار & جگ جالى زيرمعيار & زيرمعيار & وزن معيار اصلى & معيار اصلى \\
\hline $.0194 \mathrm{~V}$ & o/Orglt & $0-0 / 04$ & طول آبراهـ & \multirow{6}{*}{$\circ / 449 \circ D$} & \multirow{6}{*}{ تراكم آبراهـ. } \\
\hline .04191 &.$/ 00910$ & $0 / 04-0 / 14$ & & & \\
\hline ०/०DrVY & .०qYar & $0 / M-0 / r$ & & & \\
\hline .09119 & ./19194 & $0 / Y-0 / T V$ & & & \\
\hline - IOFGY & $\circ / T V Y \circ \Lambda$ & $\circ / Y V-\circ / T \Delta$ & & & \\
\hline$\circ / Y \backslash \wedge 9 \Lambda$ & $\circ / 4 \circ \wedge \circ q$ & $\circ / \Gamma \Delta-\circ / \Delta V$ & & & \\
\hline.$/ 01$ TVV & . OrG|K & $0-Y / T$ & 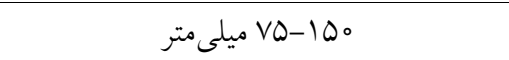 & \multirow{6}{*}{ - TAGYG } & \multirow{6}{*}{ ميزان بارندكى } \\
\hline$\circ / 0 Y) \circ D$ &.$/ \circ \Delta S 10$ & $r / Y-Y / V$ & •DU - • ا ميلى متر & & \\
\hline o/orDHA & . ०QPQAT & $r / V-V / q$ & 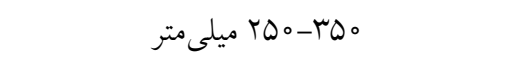 & & \\
\hline $0 / 09090$ & $0 / 19194$ & $V / 9-1 Y / 1$ & 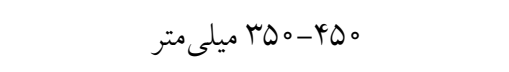 & & \\
\hline$\circ / 10 Y 01$ & $\circ / T V Y \circ \Lambda$ & $V / 9-19 / 4$ & 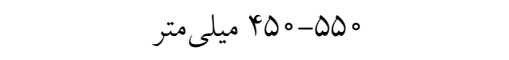 & & \\
\hline - IFATV & $\circ / 4 \circ \wedge \circ q$ & IV/Q-Mr/T & 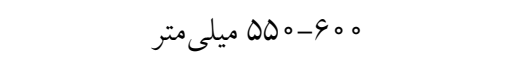 & & \\
\hline -/ovara & $\circ / 4 \circ \wedge \circ q$ & & $0-1 / 0$ & \multirow{6}{*}{ ०/IQYVR } & \multirow{6}{*}{ شيب (درجه) } \\
\hline ०/OUTA & $\circ / T V Y \circ \Lambda$ & & 1/D-r & & \\
\hline.$/ 0190$ & $0 / 19194$ & & $r-\omega$ & & \\
\hline.$/ 01 \wedge 01$ & ./.9YQR & & $\Delta-\Lambda$ & & \\
\hline .01099 &.$/ 00910$ & & $\wedge-11$ & & \\
\hline $010099 \mathrm{~V}$ & O०MGIF & & $11-10$ & & \\
\hline o/orqpy & $\circ / 4 \circ 1 \circ 9$ & & جنگل و جنگل كارى & \multirow{6}{*}{$\circ / \circ \wedge 100$} & \multirow{6}{*}{ كاربرى اراضى } \\
\hline ०० TVAq & $\circ / T V Y \circ \Lambda$ & & درياجه و زمينهاى مرطوب و زراعت آبى & & \\
\hline $.10190 \mathrm{~V}$ &.$/ 9194$ & & مرتع و ديمكارى & & \\
\hline .100999 & . ०QYDT & & 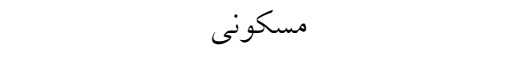 & & \\
\hline$\circ \circ \circ \Delta V Q$ & $\circ / \circ 0910$ & & 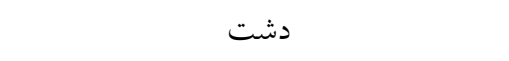 & & \\
\hline \%o०kta & orralk & & بيابان و تلماسه و زمينهاى شور & & \\
\hline$\circ / \circ \circ Y_{0} Y$ & O०MGIY & $0-0 / 0 r$ & طول گسل & \multirow{6}{*}{ \%opvrq } & \multirow{6}{*}{ 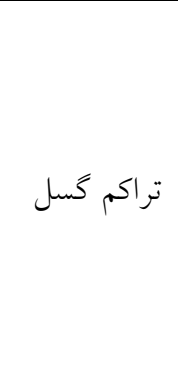 } \\
\hline 9 ל & $\circ / \circ \Delta 910$ & $\circ / 0 Y_{-0} / 09$ & & & \\
\hline .100099 & - .qrar & $0 / 09-1$ & & & \\
\hline $0 / 00999$ & $0 / 19194$ & $1-0 / 19$ & & & \\
\hline $.019 \pi \mathrm{r}$ & $\circ / T V Y \circ \Lambda$ & ०/19-0/Tr & & & \\
\hline ०/०イ & $\circ / 4 \circ 1 \circ q$ & $\circ / Y r-0 / r V$ & & & \\
\hline
\end{tabular}

بر اجراى مطالعات كسترده صحر ايى، اطلاعات موقعيت جغرافيايى نقشه براكنش جشمه و جاههاى آب بلمنظور شناسايى جشمههاى موجود در منطقه مورد مطالعه، علاوه جشمهاه و خاههاى آب در استان اصفهان از سازمان تحقيقات 


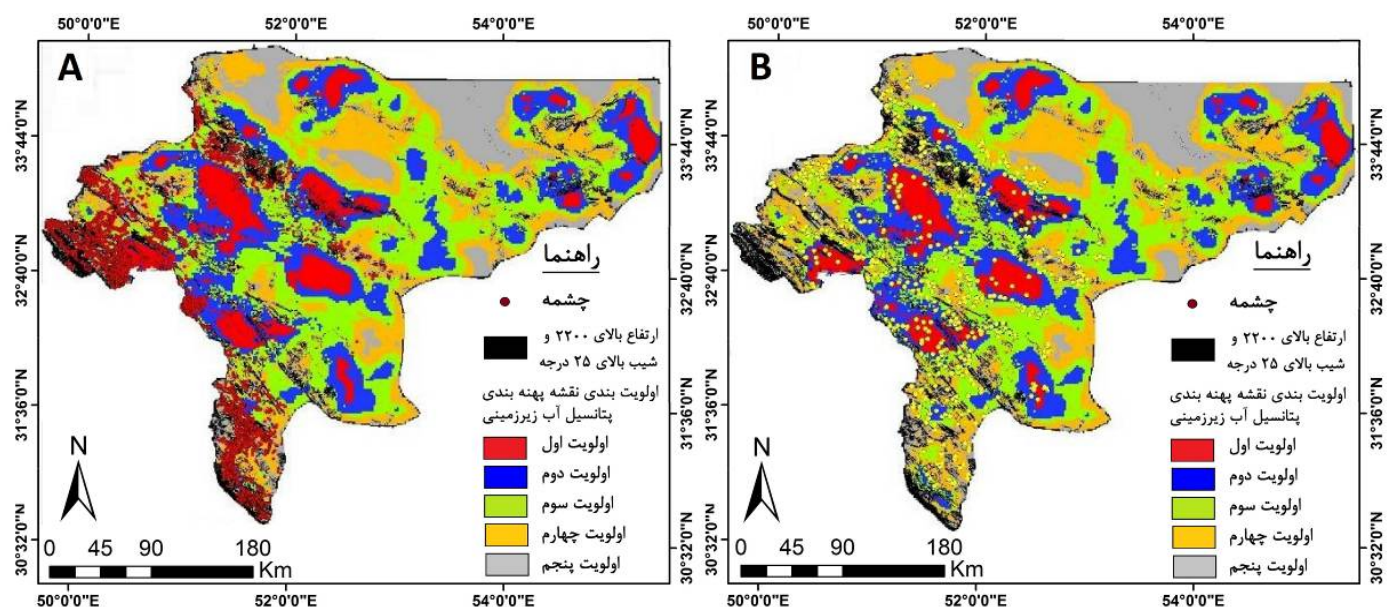

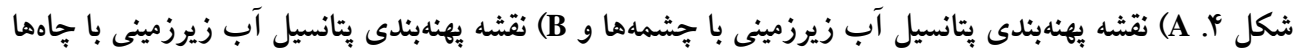

استفاده قرار كرفته است به كاركيرى نظريه مجموعههــاى فـازى

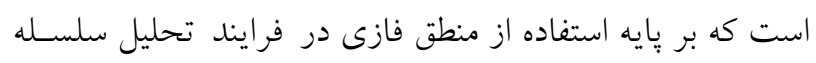

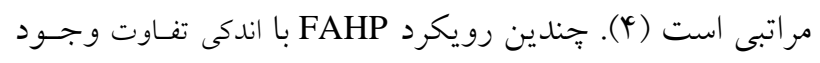

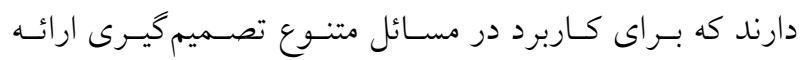

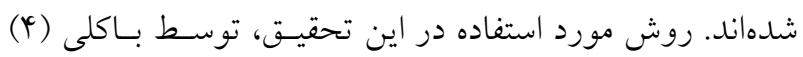
ار ائه شده است. در اين روش براى مقايسه زوجى گزينهها، از اعداد فازى و

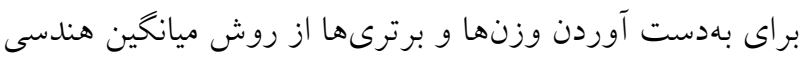

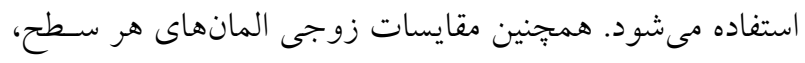

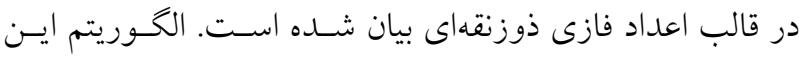
روش در سه كام اجرا مى شود. در كامهـاى اول و دوم از روش

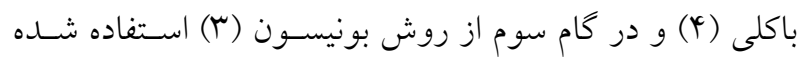

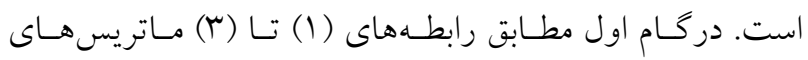
مقايسات زوجى توسط شخص تصميم گيرنده مشخص شد. $\tilde{a}_{\mathrm{ij}}=\left(\mathrm{a}_{\mathrm{ij}}, \mathrm{b}_{\mathrm{ij}}, \mathrm{c}_{\mathrm{ij}}, \mathrm{d}_{\mathrm{ij}}\right)$

$\tilde{a}_{j i}=\left(\frac{1}{d_{i j}}, \frac{1}{c_{i j}}, \frac{1}{b_{i j}}, \frac{1}{a_{i j}}\right)$

$\left[\begin{array}{ccc}\left(a_{11}, b_{11}, c_{11}, d_{11}\right) & \cdots & \left(a_{1 n}, b_{1 n}, c_{1 n}, d_{1 n}\right) \\ \vdots & \ddots & \vdots \\ \vdots & \vdots & \vdots \\ \left(a_{n 1}, b_{n 1}, c_{n 1}, d_{n 1}\right) & \cdots & \left(a_{n n}, b_{n n}, c_{n n}, d_{n n}\right)\end{array}\right]$

در كام دوم با استفاده از روش ميانخين هندسى وزن هر كدام از
منابع آب ايران كرفته شد. در مجموع 9099 جشمه و جـاه آب در استان براى ارزيابى و اعتبارسنجى نقشه يتانسيل آب زيرزمينى تهيه

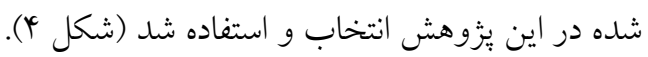

\section{الكوريتم FUZZY-AHP}

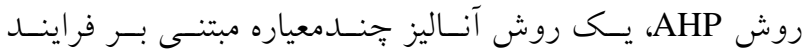

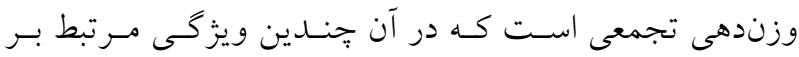

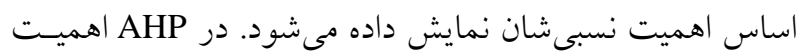

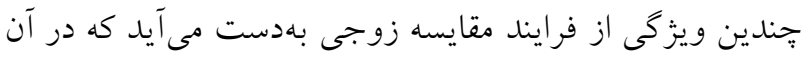

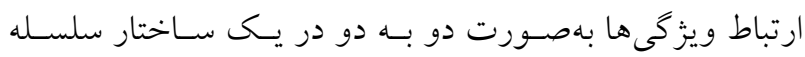

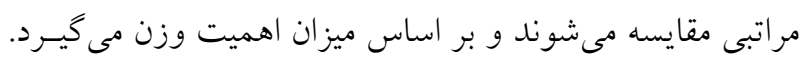

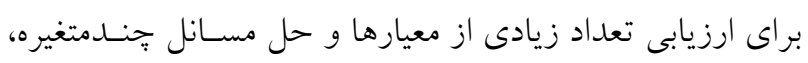

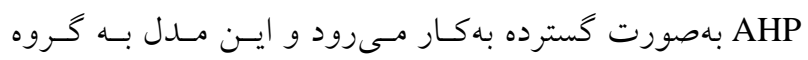

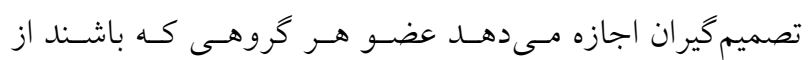

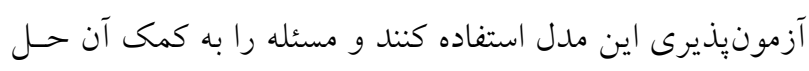

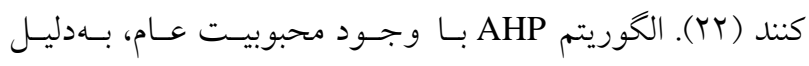

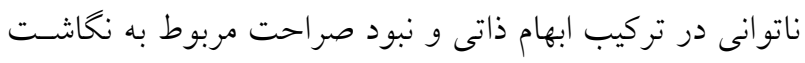

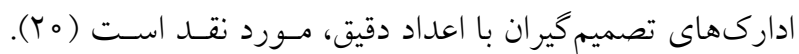

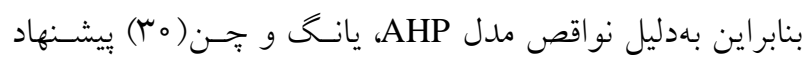
كردند كـه روش AHP در كاربردهـاى تصـميم گيــى كريستِ

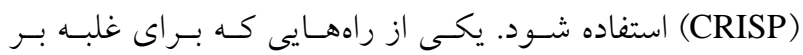

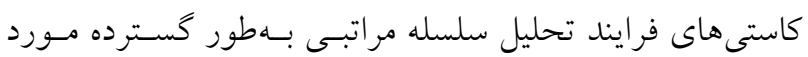


و خطواره يا گسل) در قالب لايههاى اطلاعاتى در محسيط GIS، بهمنظور تهيه نقشه بِهنهبندى بتانسيل آب زيرزمينى شده اسـت. در مرحله دوم: يس از ردهبندى، طبقات عوامل يا لايههاى مـؤثر بــر اسـاس روش FAHP وزندار (وزندهــى درون لايسـهاى و بينلايهاى) شدهاند. در مرحله سوم: لايههاى مورد نظر در محيط GIS

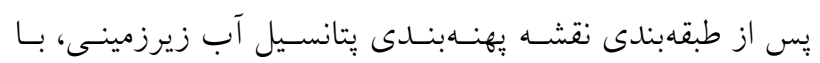

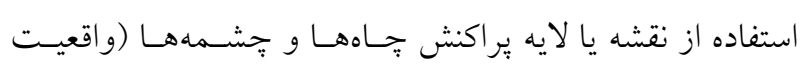
زمينىى) و بـهـكـاركيرى روش ROC اقــام بــه اعتبارسـنجى و ارزيابى نقشه نهايى شده است. در شـكل r مراحـل انجـام كـار

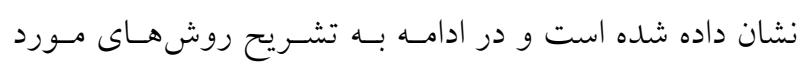
استفاده برداخته شده است.

ارزيابى و اعتبارسنجى نقشه الويتبندى يتانسـيل منـابع آب زيرزمينى

ارزيـابى يـك خـام اساسـى در توسـعه و تعيسين كيفيـت نقشـهـ

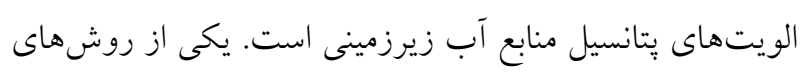
مناسب براى ارزيابى نتايج حاصل از يـك طبقـهبنـدى كنـــده و ارزيابى ميزان قابليت آن در شناسايى طبقه مورد نظر اسـتفاده از

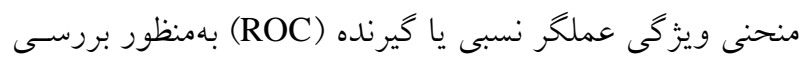
حساسيت روش است. منحنى ROC از كارآمدترين روشها در

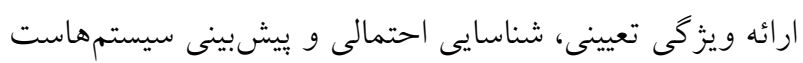

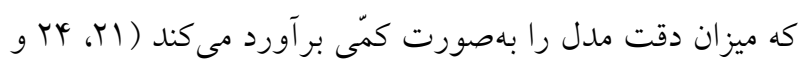

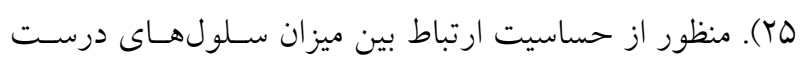
طبقهبندى شده و موارد نادرست است. هر جِه ميزان انحراف از خط مبنا براى يك طبقه خاص در منحنسى ROC بيشـتر باشـد، كارايى طبقهبندى كننده ياد شـده در شناسـايى آن طبقـهـ بيشـتر است. علاوه بر بررسى روند نمودار طبقه مورد نظر، سـطح زيـر

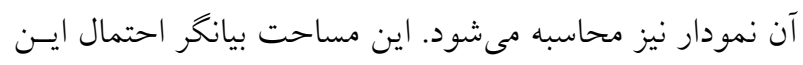
است كه يـك سـلول انتخـاب شــه بـهنور تصـادفى، صـحيح طبقهبندى مى شود و هر جّه بيشتر باشد، قابليـت اطمينـان روش

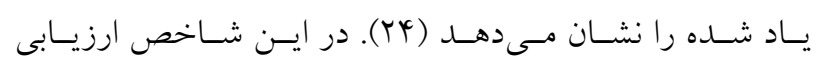

ويزگى ها (زيرلايهها) بهصـورت جداگانسه و همجنسين وزن (يـا

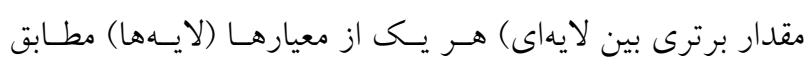

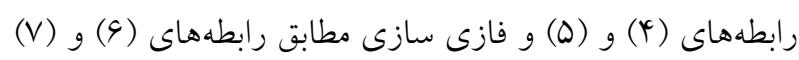
محاسبه مىشود.

$a_{i}=\left(\prod_{j}^{n} a_{i j}\right)^{1 / n}$

$\mathrm{a}=\sum_{\mathrm{i}=1}^{\mathrm{n}} \mathrm{a}_{\mathrm{i}}$

$\tilde{\mathrm{r}}_{\mathrm{ij}}=\left(\frac{\mathrm{a}_{\mathrm{i}}}{\mathrm{d}}, \frac{\mathrm{b}_{\mathrm{i}}}{\mathrm{c}}, \frac{\mathrm{c}_{\mathrm{i}}}{\mathrm{b}}, \frac{\mathrm{d}_{\mathrm{i}}}{\mathrm{a}}\right)$

$\tilde{\mathrm{W}}_{\mathrm{j}}=\left(\frac{\mathrm{a}_{\mathrm{i}}}{\mathrm{d}}, \frac{\mathrm{b}_{\mathrm{i}}}{\mathrm{c}}, \frac{\mathrm{c}_{\mathrm{i}}}{\mathrm{b}}, \frac{\mathrm{d}_{\mathrm{i}}}{\mathrm{a}}\right)$

درنهايـت در گَام سـوم بـا اسـتفاده از روش بونيسـون مقـادير

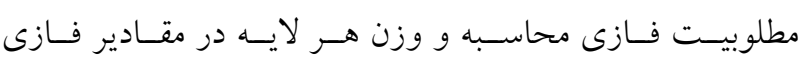
اختصاص يافته بهويز كىهاى درون لايهاى آن مطابق روابط (N)

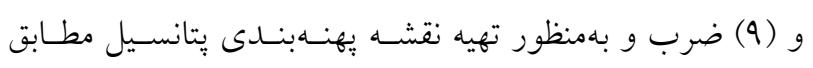
رابطه ( ا (1) محاسبه مى شود (4). $\tilde{u}_{j}=\sum_{j=1}^{n} \tilde{w}_{j} \tilde{r}^{r}$

$\tilde{w}_{j} \tilde{r}_{i j}=\left(\begin{array}{l}a_{1} b_{r}, b_{1} b_{r}, a_{1} l_{r}+a_{r} l_{1} \\ -l_{1} l_{r}, b_{1} r_{r}+b_{r} r_{1}+r_{1} r_{r}\end{array}\right)$

$z^{*}=\frac{a+b}{r}$

يس از محاسبه وزن مربوط به هر لايه بـر اسـاس روش FAHP كه در حقيقت اهميت هر لايه را در تشكيل آب زيرزمينى نشان

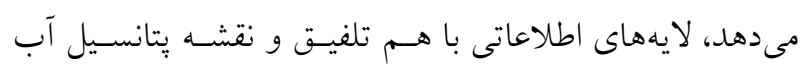
زيرزمينـى تهيـهـ شــــ تلفيـق نقشـهـهــاى معيــار در نرمافـزار ArcGIS 10.1 روشهاى مورد اسـتفاده در ايسن تحقيـق نيـز شـامل روش FAHP

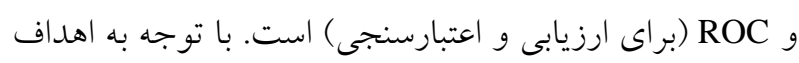

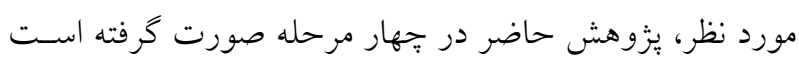
كه در ادامه به تشريح مراحل پيرداخته شده است: در مرحله اول:

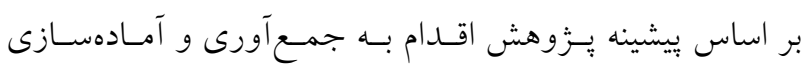

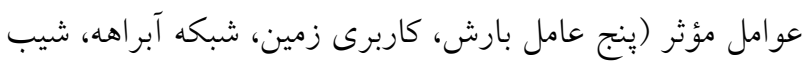


ضعيف) است (Y و Y (YV). هر خه سطح منحنى به يك نزديكتـر

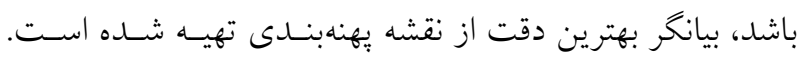

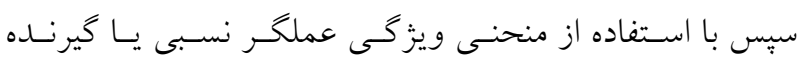

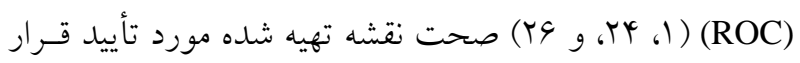

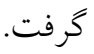

بدينمنظور از يراكنش نقاط خشمه و خاه بهعنـوان واقعيـت زمينى براى ارزيابى و دقت طبقهبندى نقشه الويتهاى يتانسـيل

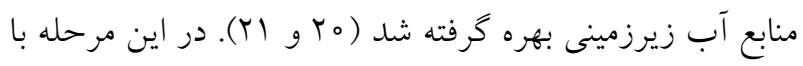
تلاقى نقشه ير اكنش جشمههاى منطقه بهعنوان يَّانسيل بالفعل و

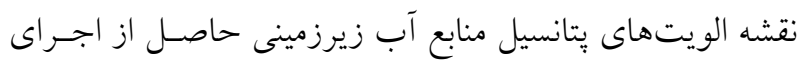

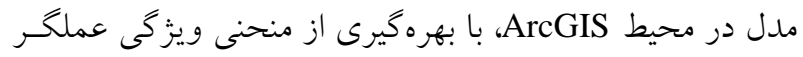
نسبى (ROC) بهارزيابى اعتبارسنجى نقشه الويتهـاى يتانسـيل منابع آب زيرزمينى يرداخته مىشود.

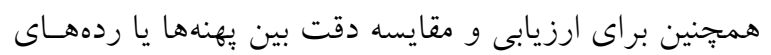

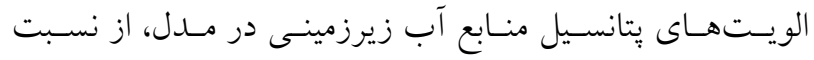

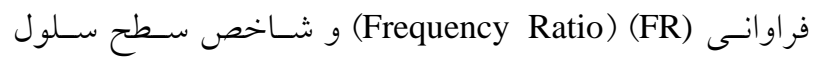
هسته (SCAI) استفاده شده است. به بيانى ديخــ بـا اسـتفاده از

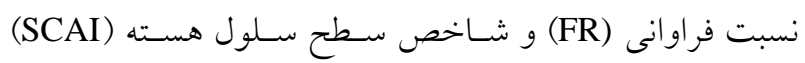

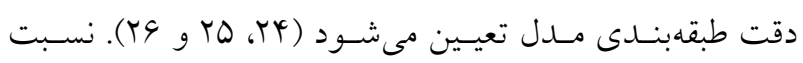

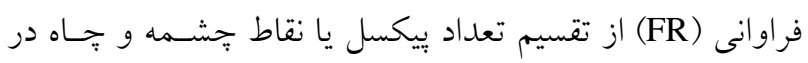

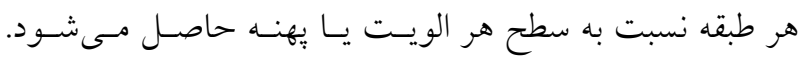

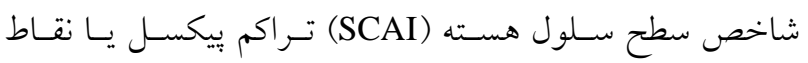
جشمه و جاه در هر طبقه است و از تقسيم درصد سطح هر يهنه

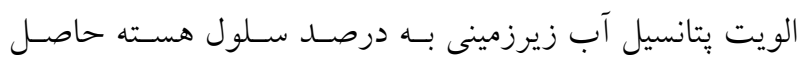
مىشود.

\section{بحث و نتايج}

نتايج وزندهى به عوامل مؤثر براساس الخوريتم FAHP

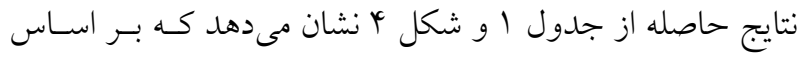

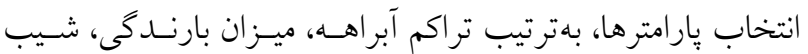

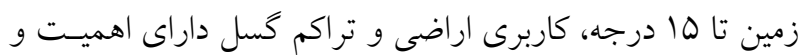

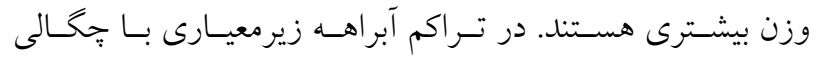

سلولهايى كه به درستى به طبقه مورد نظر اختصاص يافتسهانــــ

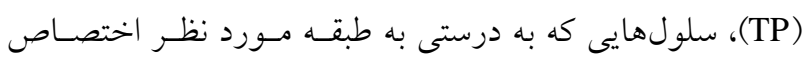

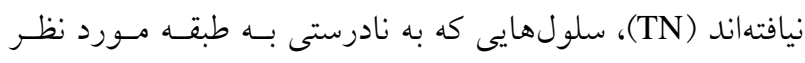

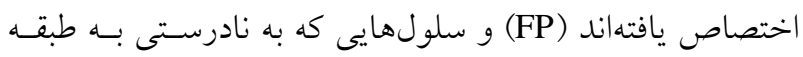
مورد نظر اختصاص نيافتهاند (FN)، استفاده مىشوند.

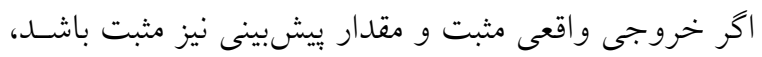

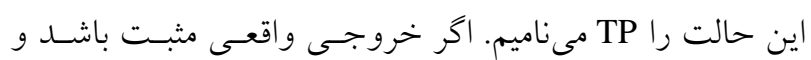

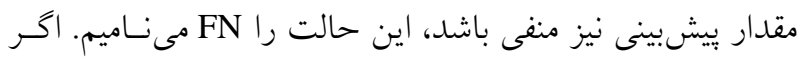
خروجى و اقعى منفى و مقدار ييشبينى نيـز منفـى باشـد، ايـنـ

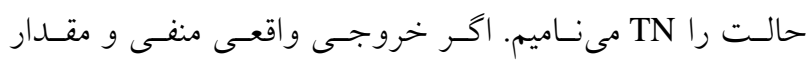
ييشبينى نيز مثبت باشد، اين حالت را FP مىنساميم. در ترسيم نمودار ROC حساسيت (Sensitivity) بيانكر مقـادير ييشيينى

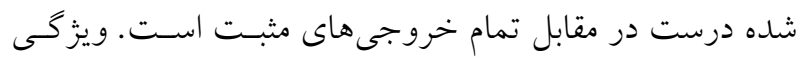

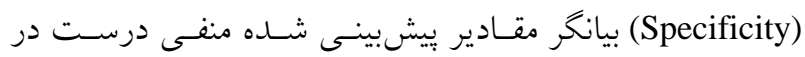
مقابل تمام خروجى هـاى منفى اسـت. در صـورتى كـه مقــدار

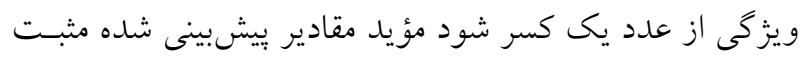

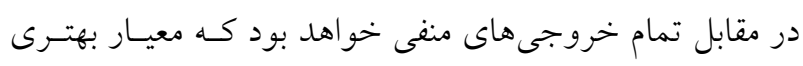

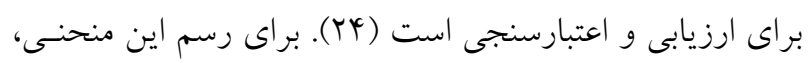

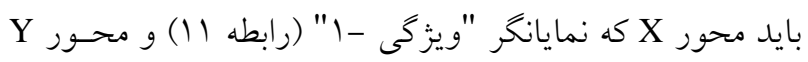

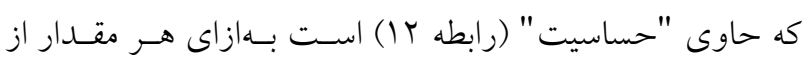
آستانه طبقه مورد نظر محاسبه شود.

$$
\begin{aligned}
& 1-\text { ويزگ }=\frac{\mathrm{TP}}{\mathrm{TN}+\mathrm{FP}} \\
& \text { TP+FN }
\end{aligned}
$$

سطح زير منحنى Area Under Curve) AUC كه ROC ناميده مىشود، بيانكر مقدار بيشبينى سيستم از طريق توصيف توانايى مانى

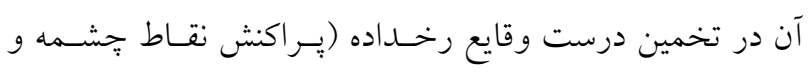

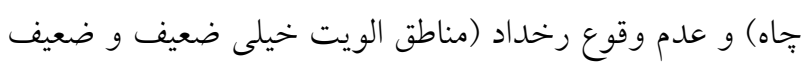

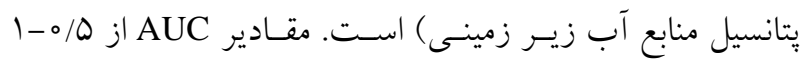

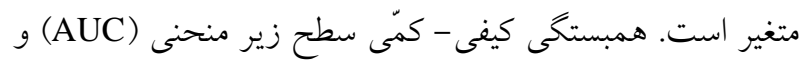

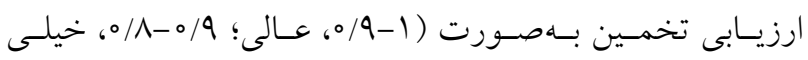

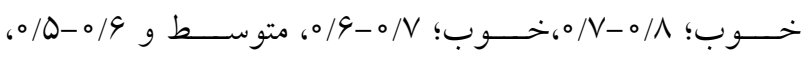




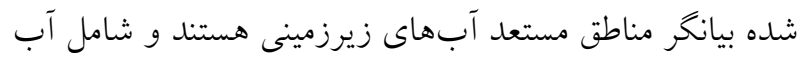

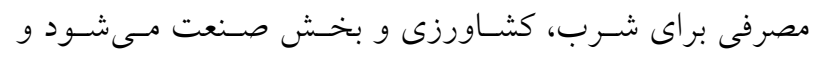

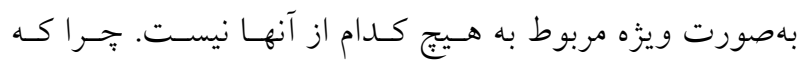

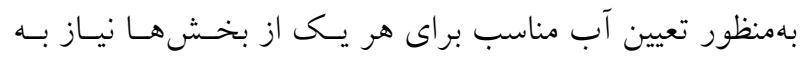

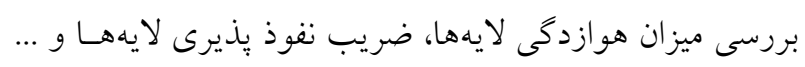

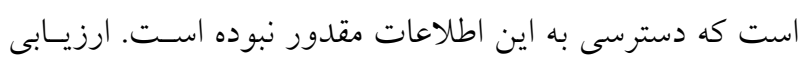

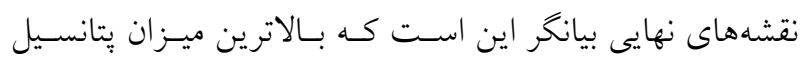

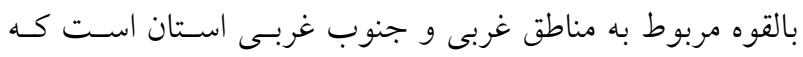

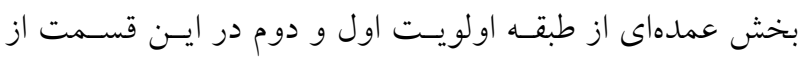

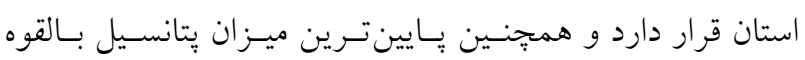

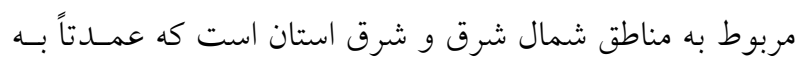

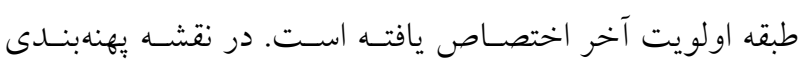

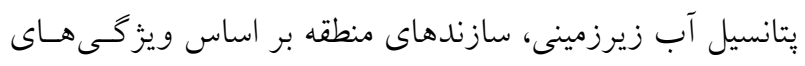

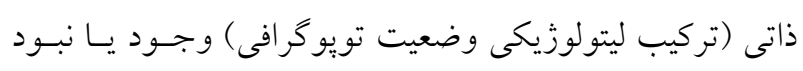

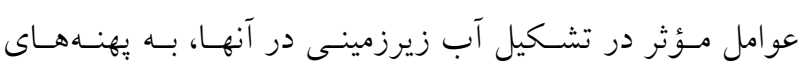

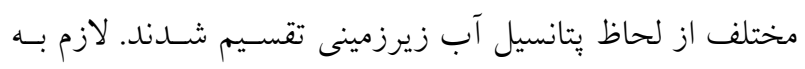

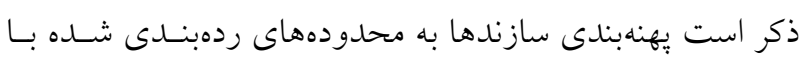

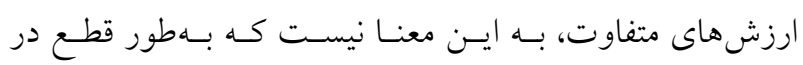

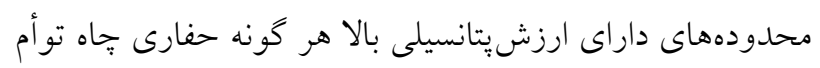

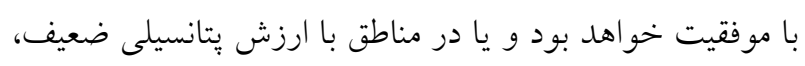

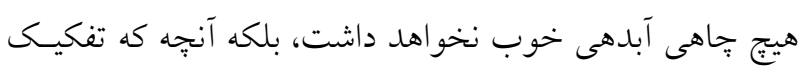

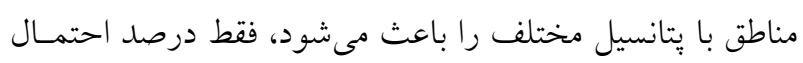

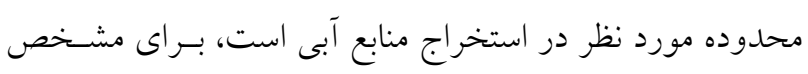

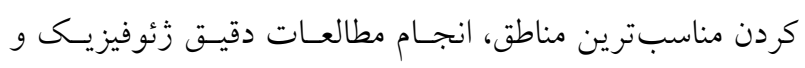

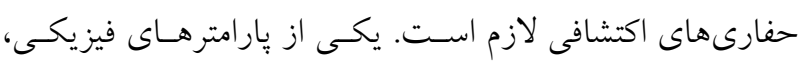

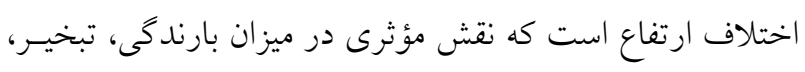

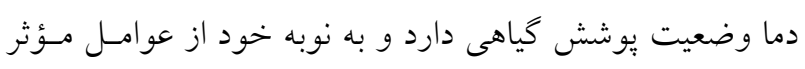

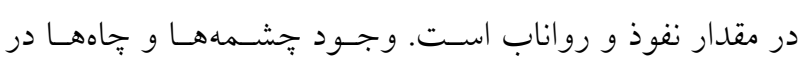

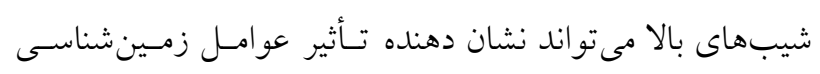

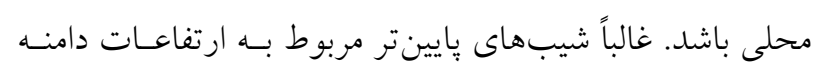

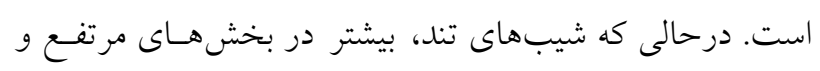

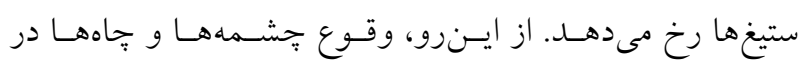

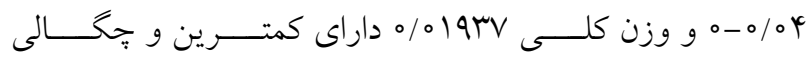

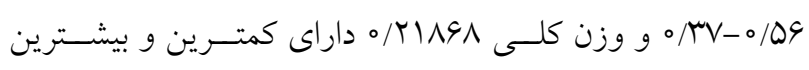

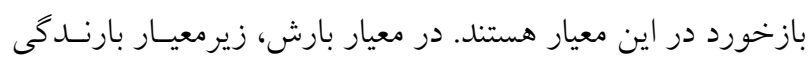

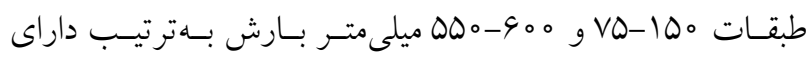

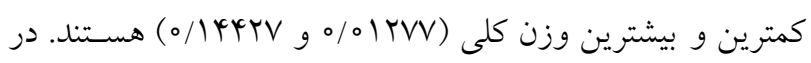

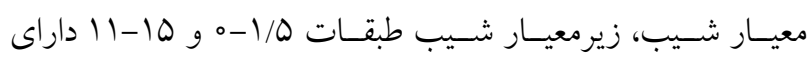

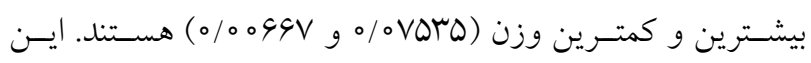
بدين مفهوم است كه شيبهاى كمتر اثر بيشترى دارنــــ در معيـار

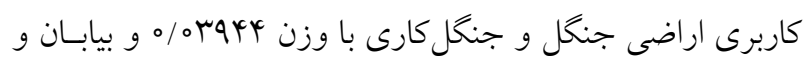

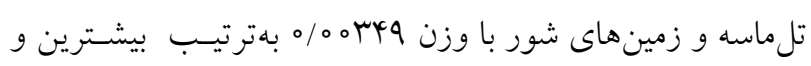

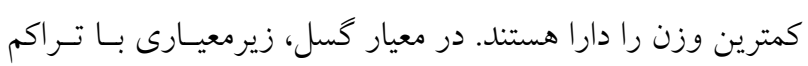

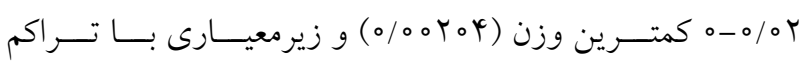
إك

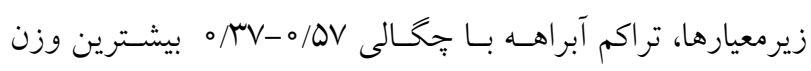

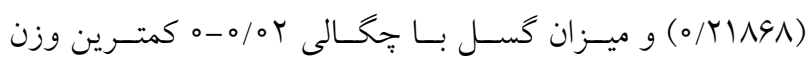

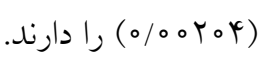

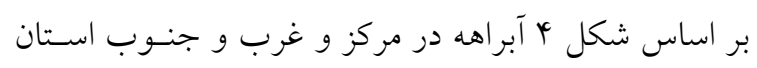

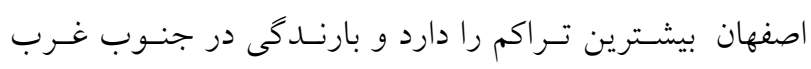

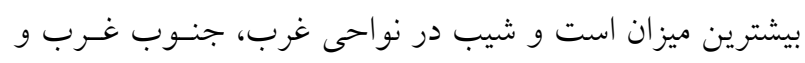

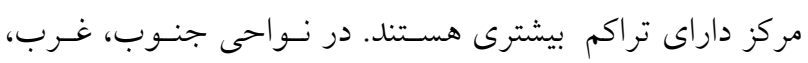

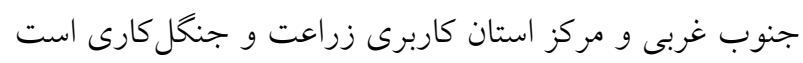

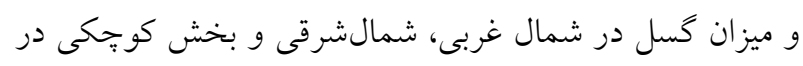
غرب و جنوب داراى بيشترين تراكم هستند.

منطقه مورد مطالعه

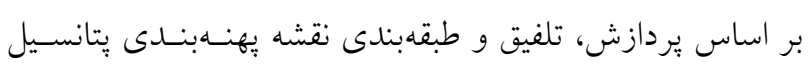

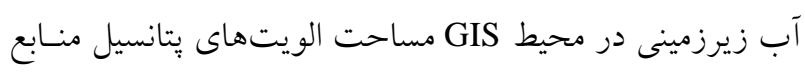

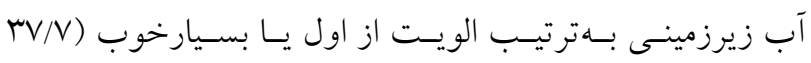

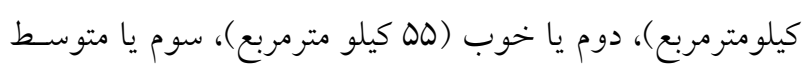

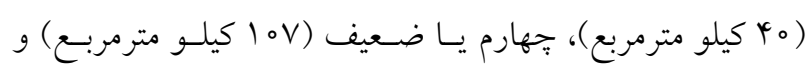

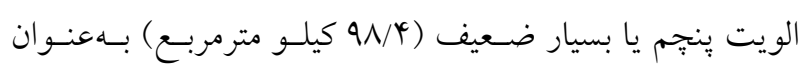
مناطق بيشنهادى مشخص شدند (شكل ؟). نقشههاى نهايى تهيه 
ردهاى الويت بسيار خوب و خــوب داراى مقــادير خيلى كـم

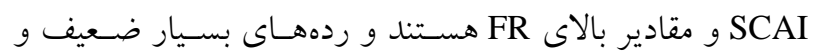

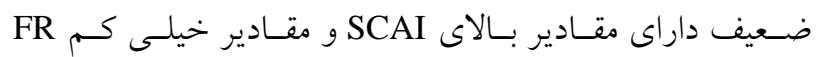

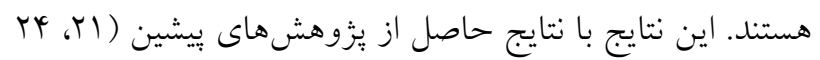

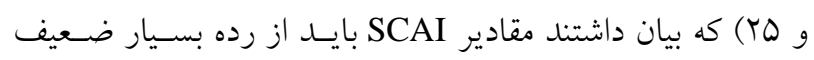

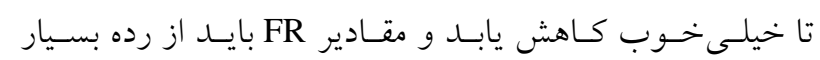

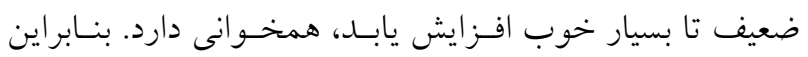
همبستخى بالاى ردههاى طبقات يتانسيل آب زيرزمينى با تـر اكم

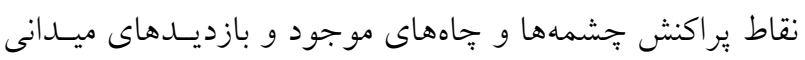

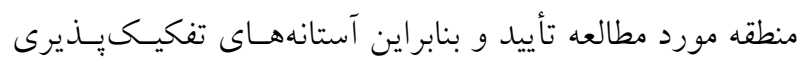

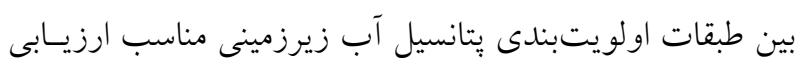

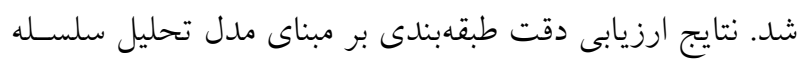

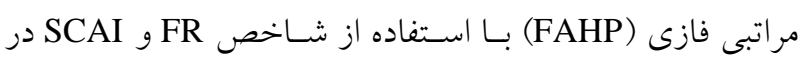

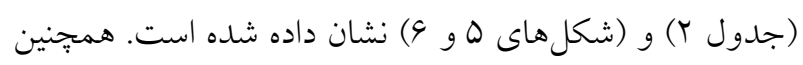

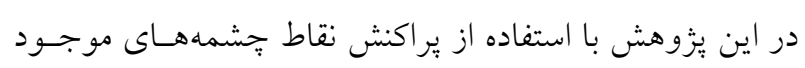

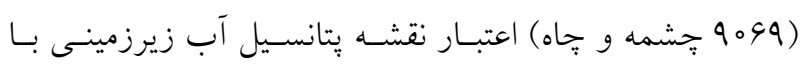

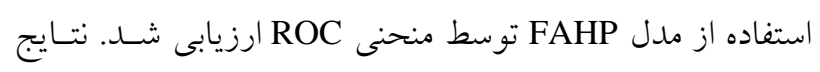

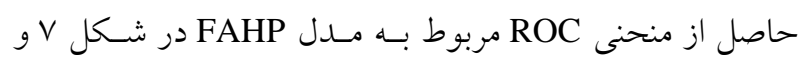

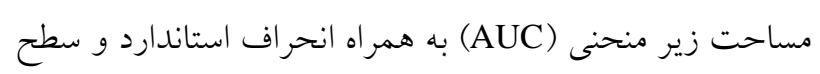

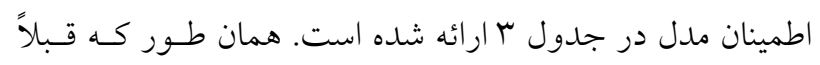

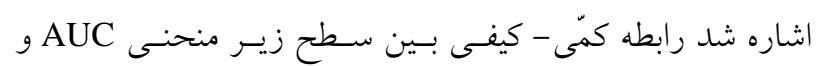

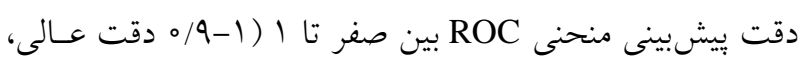

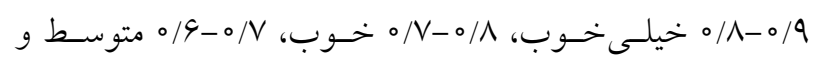

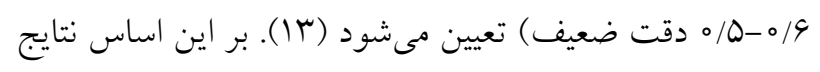

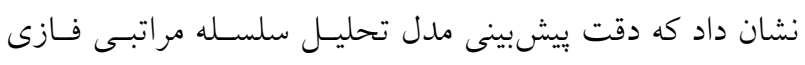

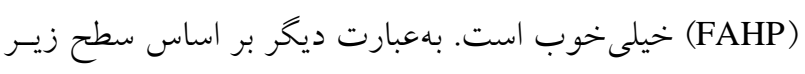

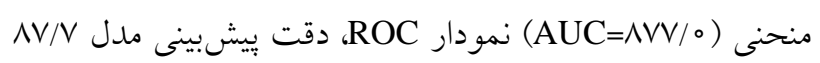

$$
\text { درصد تعيين مىشود. }
$$

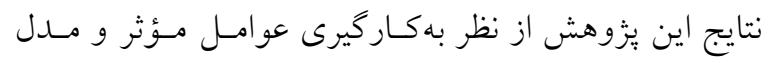

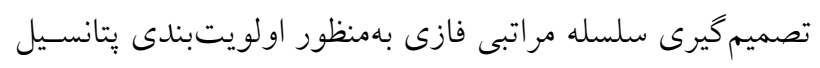

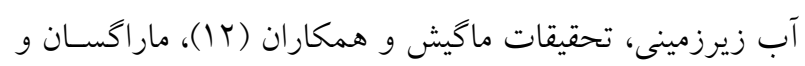

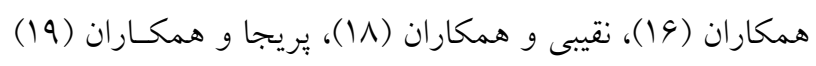

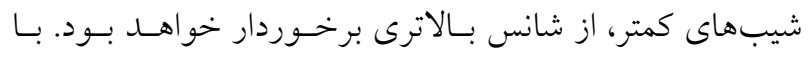

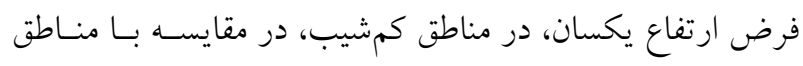

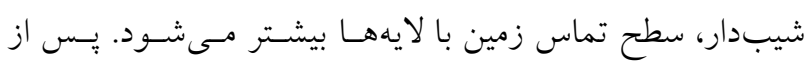

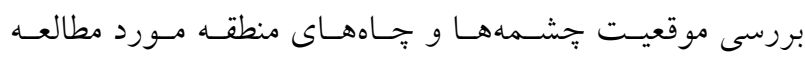
مشخص شد كه بيشتر جشمهها و جّاهها كه در نقاط مرتفع قرار

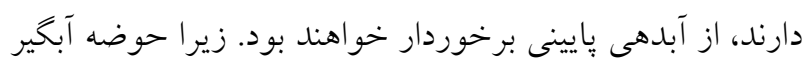

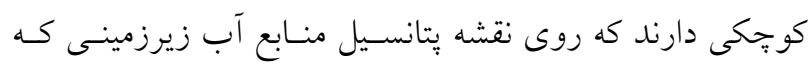

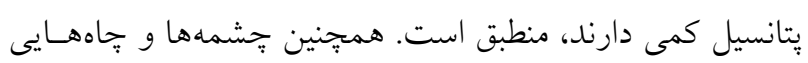
با آبدهى زياد كه در مناطقى با شيب پايين قرار دارند دقيقاً روى همئ

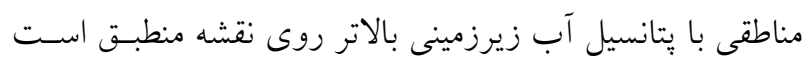

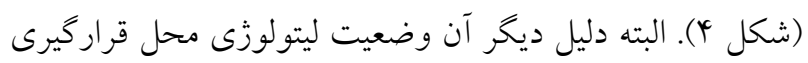

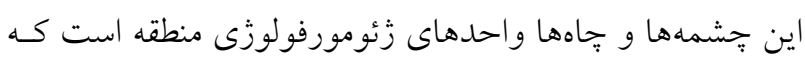
در سلسله مر اتبى تحليلى فازى لحاظ شده اسـت. نتسايج نشـان ونسان

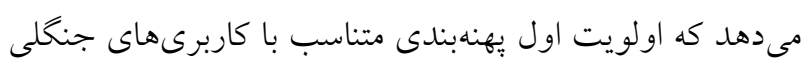

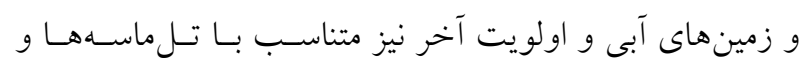

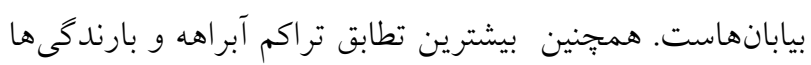

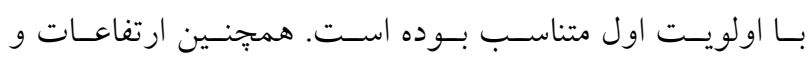

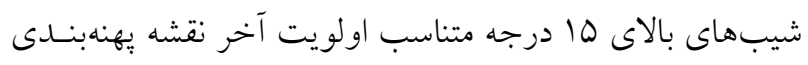

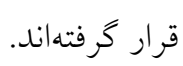

\section{نتايج ارزيابى دقت و اعتبارسنجى نقشه الويست پِتانسـيل آب زيرزمينى در منطقه مورد مطالعه}

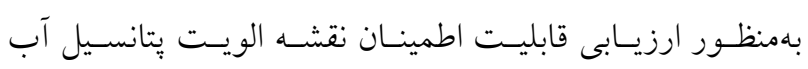

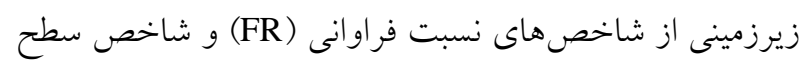

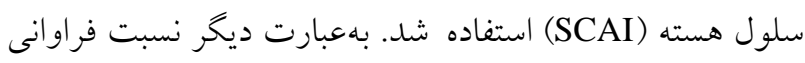
و شاخص SCAI دو شاخصى هستند كه دقت طبقدبنـى (FR)

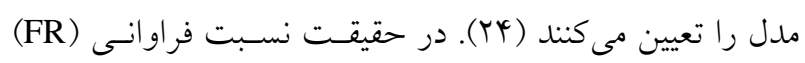

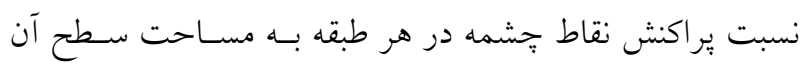
طبقه و شاخص SCAI نسبت درصد مساحت هر يك از طبقات

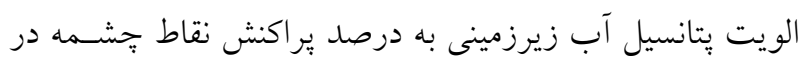

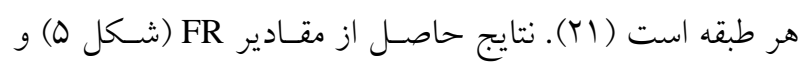
SCAI 
جدول r. نسبت فراوانى (FR) و شاخص SCAI ردههاى يُانسيل آب زيرزمينى به روش تحليل سلسله مراتبى فازى (FAHP)

\begin{tabular}{|c|c|c|c|c|c|}
\hline 0 & $r$ & r & r & 1 & 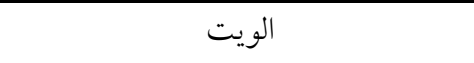 \\
\hline خيلى كم & كم & 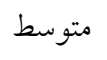 & زياد & خيلى زياد & ردههاى يتانسيل آب زيرزمينى \\
\hline 1091 & rits & $09 \Lambda$ & rG. & rgY. & تعداد جشمهها و جاههاى درون اولويت \\
\hline $\mid r / 0 r$ & $r \mu / 9 \mathrm{~V}$ & $9 / 90$ & rN/9Q & $r q / 01$ & درصد جشمهها و جاههاى درون اولويت \\
\hline $91 / 4$ & $10 V / 49$ & ro & $\Delta \Delta$ & rV/V & مساحت هر رده يتانسيل (كيلومترمربع) \\
\hline$r q / 09$ & MING & $11 / 11$ & $19 / 70$ & $11 / 14$ & درصد مساحت رده \\
\hline $11 / 09$ & $19 / 9 \mathrm{~V}$ & $14 / 90$ & $r v / r q$ & $99 / 19$ & نسبت فراوانى (FR) \\
\hline $9 / 10$ & $I T / T Q$ & $9 / 1 V$ & $r q / \circ \circ$ & ET/VA & درصد Seed \\
\hline$Y / T V$ & $r / 09$ & $1 / 79$ &.$/ 09$ & $0 / 49$ & SCAI \\
\hline
\end{tabular}

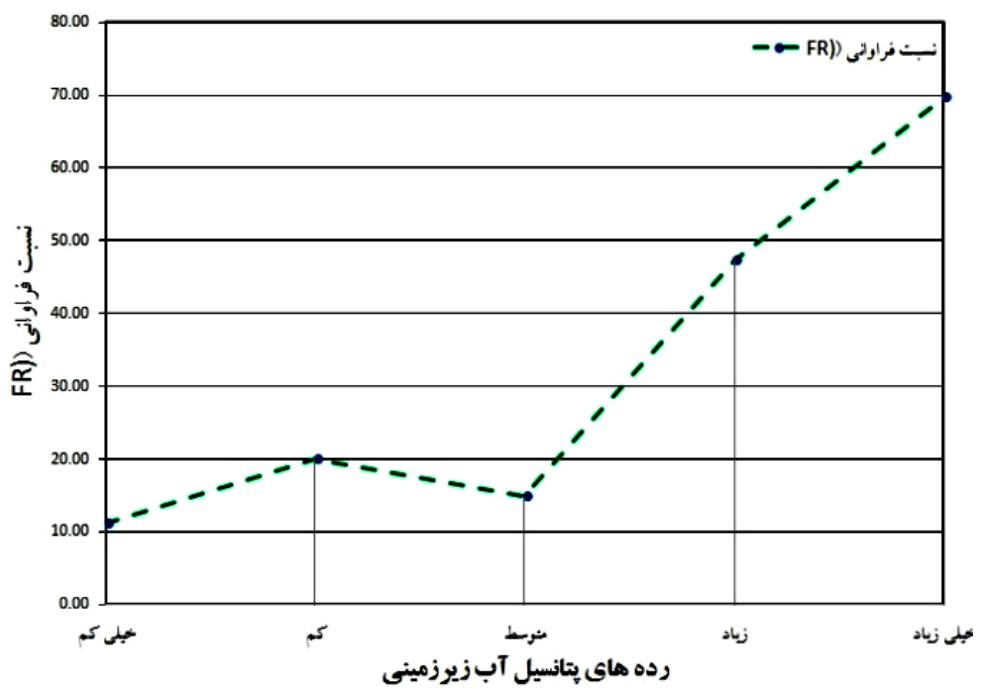

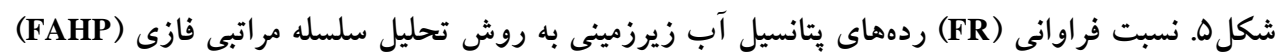

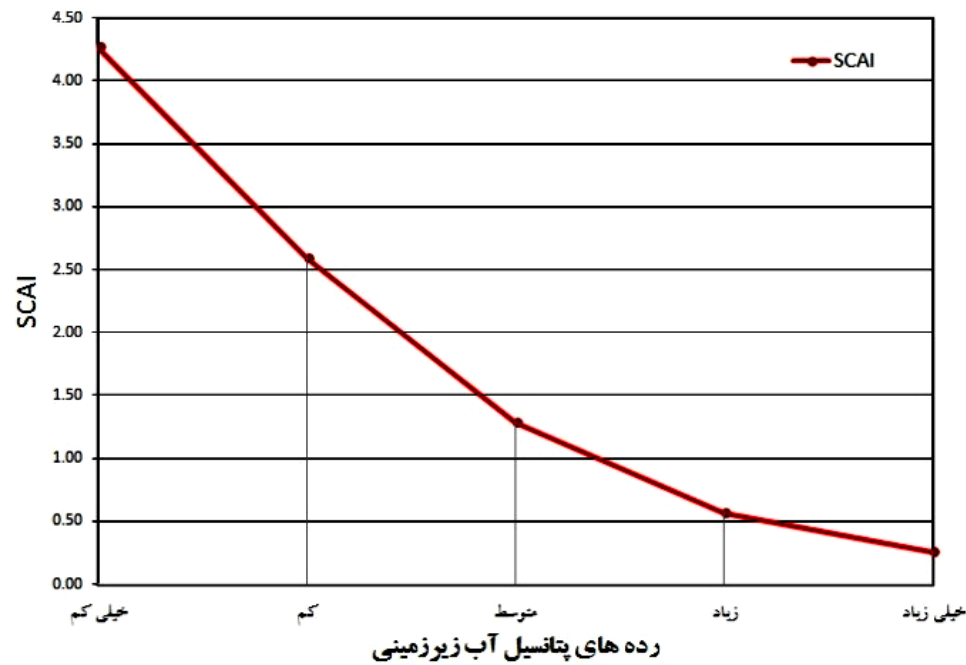

شكل צ. شاخص SCAI ردههاى بتانسيل آب زيرزمينى به روش تحليل سلسله مراتبى فازى (FAHP) 
جدول r. مساحت زير منحنى ROC بههمراه انحراف استاندارد و سطح اطمينان آن

\begin{tabular}{|c|c|c|c|c|}
\hline \multicolumn{2}{|c|}{ سطح اطمينان ه9 درصد } & \multirow{2}{*}{ سطح اطمينان } & \multirow{2}{*}{ انحراف استاندارد } & \multirow{2}{*}{ سطح زير منحنى ROC } \\
\hline حد بايين & حد بالا & & & \\
\hline$\circ / V Q H$ & $1 / 000$ & $\circ / 0 \circ 0$ & $0 / 09 \mu$ & $\circ / \Lambda V V$ \\
\hline
\end{tabular}

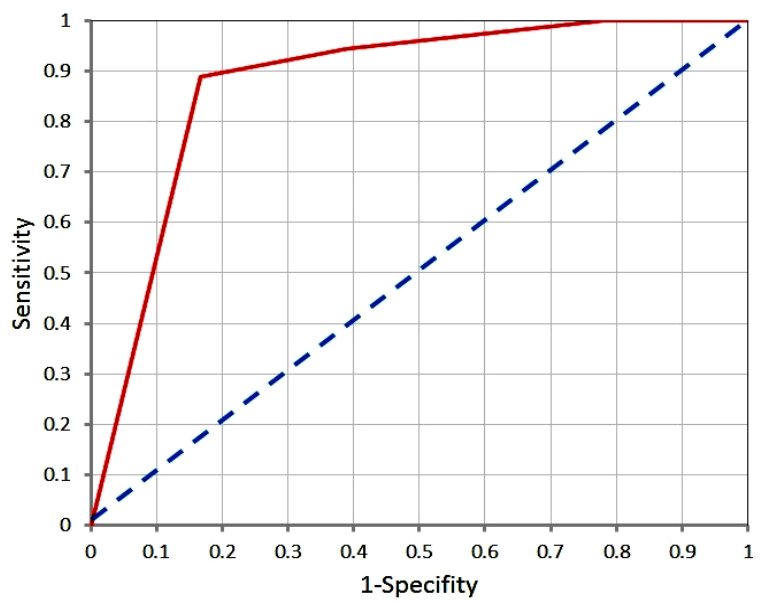

شكل V. منحنى نرخ بيشبينى (ROC) روش تحليل سلسله مراتبى فازى (FAHP) براى ردههاى بتانسيل آب زيرزمينى

زمينشناسـى صـحر ايى مانـــ اطلاعـات مربـوط بـه جــاههـاى

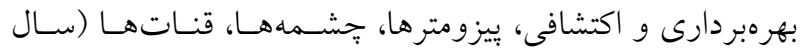
آمارى ه0-94) صحتسنجى شود. مساحت الويت هاى يتانسيل

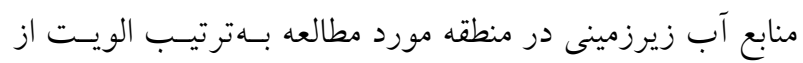

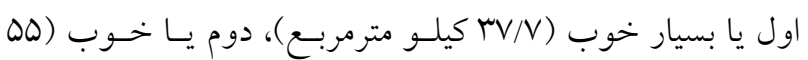
كيلو مترمربع)، سوم يا متوسط (ب0 كيلـو مترمربـع)، تهــارم يـا

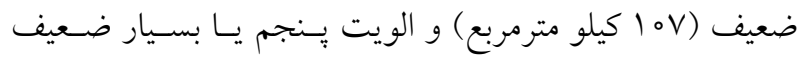

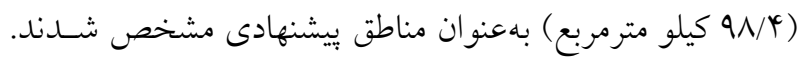
بهمنظور صحتسنجى عمل يتانسـيل يابى آب زيرزمينسى منطقـه

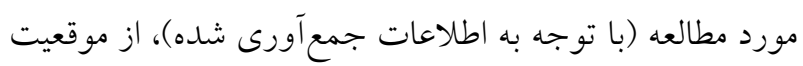

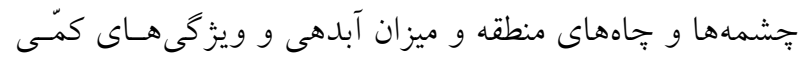

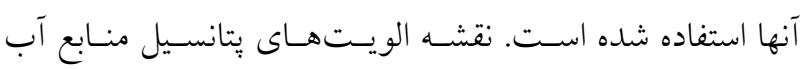
زيرزمينى با استفاده از يراكنش نقاط جشمههاى موجود، نسـبت فراوانسى (FR)، شــاخص SCAI و منحنسى ROC ارزيــابى و اعتبارسنجى شد. نتايج نشان داد نسبت فراوانى بيكسل هـا (FR) و شاخص سطح سلول هسـته (SCAI) مبـين صسحت مناسـب طبقهبندى در ينج طبقه يتانسيل اسـت. همدِنسين دقـت نمـودار
را تأييد مى كند. همه افراد مذكور استفاده از مــل ييشـنهادى را در شناسـايى منـاطق مسـتعد آب زيرزمينسى كارآمــد مسى دانـــد. همجنين اين يزوهش از نظر كارآمدى بهكار گيرى شاخص هــاى

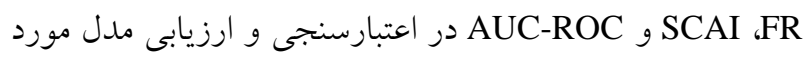
اسـتفاده، تحقيقـات رضـوى و همكــاران (Iال)، شـيرانى (YY)، شيرانى و عربعامرى (YO)، منصورى و شيرانى (Y) و سوزان و دورايان (YV) را كه در زمينه مــلهـاى مبتنى بــر دادهكـاوى

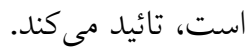

\section{نتيجه گيرى}

آنجهه در زمينه نتايج حاصل از يتانسيليابى آب زيرزمينى اهميت

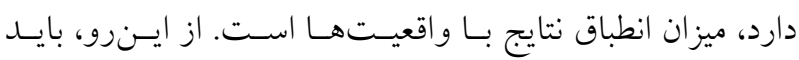

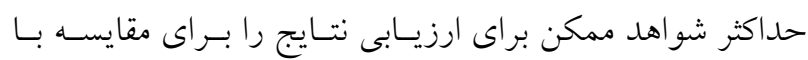
واقعيتهاى موجود و همجنين، هماهنكى بـا قـوانين و شـرايط فيزيكى حاكم بر سيستم طبيعى، مورد استفاده قـرار داد. در هـر

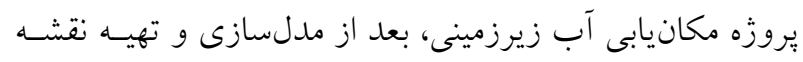

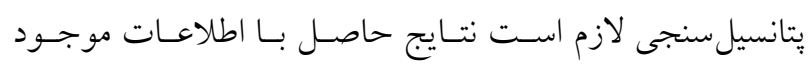




$$
\begin{aligned}
& \text { بيشنهاد مى شود در زمينه تهيه نقشه الويتهـاى يتانسـيل منـابع }
\end{aligned}
$$

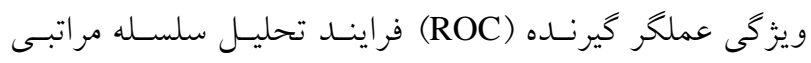

$$
\begin{aligned}
& \text { آب زيرزمينى در مناطق ديخر با مقياس كو جك نيـز ايسن روش } \\
& \text { فازى (FAHP) با سطح زير منحنى (AUC) \ـ درصد، نماينـده } \\
& \text { استفاده شود، البته شكى نيست براى مناطق بزرگمقياس در نظر } \\
& \text { همبستخى بالا بين نقشه يتانسيل تهيه شده و نقشه براكنش نقاط }
\end{aligned}
$$

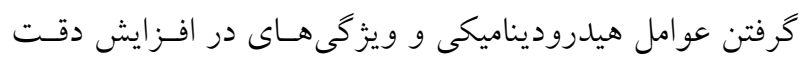

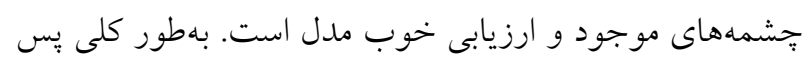

$$
\begin{aligned}
& \text { نقشه يتانسيل آب زيرزمينى مى تواند نقش بسزايى داشـته باشـد. } \\
& \text { نتايج اين يزووهش بهعنوان اطلاعات يايهاى در مقياس تفصسيلى }
\end{aligned}
$$

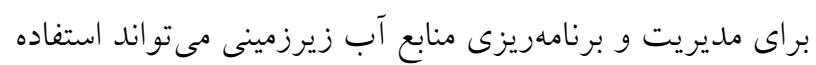

$$
\begin{aligned}
& \text { شود. }
\end{aligned}
$$

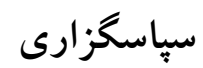

$$
\begin{aligned}
& \text { از اجراى اين يزوهش با توجه به هدف تعيين شـده، بـا تعيسين }
\end{aligned}
$$

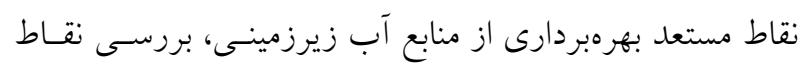

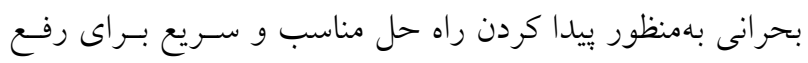

$$
\begin{aligned}
& \text { مشكل فرونشست دشتها و ايجاد يكى بانك اطلاعاتى مدون و } \\
& \text { مـنظم در محسيط GIS بـهنظــور سـرعت عمــل بخشـيدن بـه. } \\
& \text { يززوهشهاى آتى با بهره گيرى از مدل FUZZY-AHP در بسـتر } \\
& \text { دادهها و اطلاعات تكميلـى مـورد نيـاز ايسن نـزَوهش از مركـز } \\
& \text { GIS امكان بررسىهـاى دقيـقتـر در مقيـاس محلـى را فــراهم } \\
& \text { تحقيقات و آموزش كشاورى و منابع طبيعى اصفهان و اداره آب }
\end{aligned}
$$

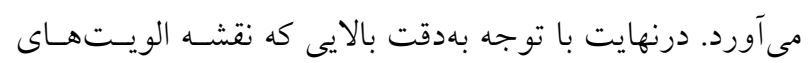

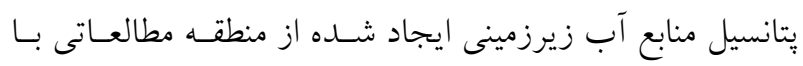

$$
\begin{aligned}
& \text { منطقهاى اصفهان تهيه شدند. همجنــين طـى مراحـل بررسى و } \\
& \text { يذيرش اين مقاله، از نظرات و يِيشنهادات بسـيار ارزنسده داوران } \\
& \text { محترم و ناشناس در ارتقاى نتايج دقيقتر استفاده شد. از ايسنرو } \\
& \text { نويسند گان مراتب تقدير و تشكر را نسبت به آن مركـز، اداره و } \\
& \text { داوران محترمى كـه زحمـت داورى را بـهـهـــه داشـتند، ابــراز } \\
& \text { مى كنند. } \\
& \text { استفاده از روش تحليل سلسله مراتبى فازى (FAHP) دارد، اين } \\
& \text { نقشه مىتواند بهمنظور مديريت بهينـه توسـط تصـميم گيـران و }
\end{aligned}
$$

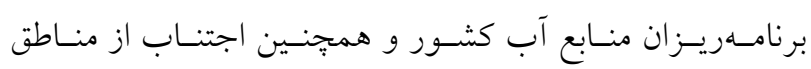

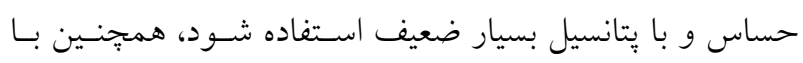

$$
\begin{aligned}
& \text { توجه بهدقت بالاى تحليـل سلسـله مراتبى فـازى (FAHP) در }
\end{aligned}
$$

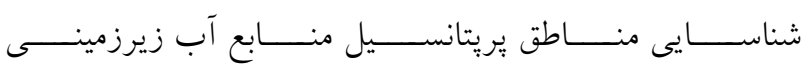

\section{منابع مورد استفاده}

1. Asadi, S. S., P. Neela Rani, B.V.T. Vasantha Rao and M.V. Raju. 2012. Estimation of groundwater potential zones using Remote sensing and Gis: A model study. International Journal of Advanced Science and Technology (2): 265276.

2. Basavaraj, D. B., C. G. Hiremath, J. Davithuraj and B. K. Purandara. 2016. Identification of groundwater potential zones using ArcGIS 10.1. International Journal of Civil, Mechanical and Energy Science 2394-2827.

3. Bonissone, P. P. 1982. A Fuzzy Sets Based Linguistic Approach: Theory and Application, PP. 329-339. In: Gupta, M. M. and E. Sanchez (Eds.) Approximate Reasoning in Decision Analysis, North-Holland.

4. Buckley J. J. 1985. Fuzzy Hierarchical Analysis. Fuzzy Sets and Systems 17: 233- 247.

5. Chenini, I, A. B. Mammou and M. May. 2010. Groundwater recharge zone mapping using GIS-based multi-criteria analysis: a case study in Central Tunisia (Maknassy Basin). Water Resources Management 24(5): 921-39.

6. Davoodi Moghaddam, D., M. Rezaei, H. R. Pourghasemi, Z. S. Pourtaghi and B. Pradhan. 2015. Groundwater spring potential mapping using bivariate statistical model and GIS in the Taleghan watershed, Iran. Arabian Journal of Geosciences 8(2): 913-929.

7. Deepesh, M., K. Madan, and C. Bimal. 2011. Assessment of groundwater potential in a semi-arid region of india using remote sensing, GIS and MCDM techniques. Water Resources Management (25): 1359-1386.

8. Dixon, B. 2009. A case study using SVM, NN and logistic regression in a GIS to predict wells contaminated with Nitrate-N. Hydrogeology Journal 17(6): 1520-1527.

9. Ganapuram, S., G. V. Kumar, I. M. Krishna, E. Kahya and M. C. Demirel. 2009. Mapping of groundwater potential zones in the Musi basin using remote sensing data and GIS. Advances in Engineering Software 40(7): 506-18. 
10. Israil, M., M. Al-hadithi and D. Singhal. 2006. Application of a resistivity survey and geographical information system (GIS) analysis for hydrogeological zoning of a piedmont area: Himalayan foothill region, India. Hydrogeology Journal 14: 753-9.

11. Lee, M. J., I. Park and S. Lee. 2015. Forecasting and validation of landslide susceptibility using an integration of frequency ratio and neuro-fuzzy models: a case study of Seorak mountain area in Korea. Environmental Earth Sciences 74(1): 413-29.

12. Magesh, N. S., N. Chandrasekar and S. John Prince. 2012. Delineation of groundwater potential zones in Theni district, Tamil Nadu, using remote sensing, Gis and Mif techniques. Geo-Science Frontiers 2: 189-196.

13. Mahmoudi, D., M. Rezaei, M. Dashti Barmaki and K. Rezaei. 2014. Hydrostratigraphy investigation for identifiying of groundwater potential zones using geophysical and sedimentological data (case study: Kordan plain, Karaj), Journal of Water Resources Development 2(5): 104-115.

14. Mansouri, M., K. Shirani, A. Ghaziphard and S. N. Emami. 2016. Landslide hazard zonation using Entropy and Weight of Evidence methods (Case study: Dow ab Samsami, Chahar Mahal \& Bakhtiyari), Geosiences 1(26): 267280.

15. Mukherjee, P., C. K. Singh and S. Mukherjee. 2011. Delineation of groundwater potential zones in arid region of India, a remote sensing and GIS approach. Water Resources Management 26: 2643-2672.

16. Murugesan, B., R. Thirunavukkarasu, V. Senapathi and G. Balasubramanian. 2012. Application of remote sensing and GIS analysis for groundwater potential zone in kodaikanal Taluka, South India. Journal of Earth Science 7(1): 65-75.

17. Nabavi, M. H. 1976. Introduction to Iran Geology, Iran Geology Survey, 94p.

18. Naghibi, S. A., H. R. Pourghasemi, Z. S. Pourtaghi and A. Rezaei. 2015. Groundwater qanat potential mapping using frequency ratio and Shannon's entropy models in the Moghan watershed, Iran. Journal of Earth Science 8(1): 171-86.

19. Preeja K. R., J. Sabu, J. Thomas and H. Vijith. 2011. Identification of Groundwater Potential Zones of a Tropical River Basin (Kerala, India) Using Remote Sensing and GIS Techniques. Journal of the Indian Society of Remote Sensing 39(1): 83-94.

20. Ramu, H.; B. Mahalingam and M. Vinay. 2014. Identification of ground water potential zones using GIS and Remote Sensing Techniques: A case study of Mysore taluk-Karnataka. International Journal of Geomatics and Geosciences (3): 976-4380.

21. Razavi Termeh, S. V., K. Shirani and M. Soltani Rabi. Groundwater potential mapping using integrating weight of evidence and logistic regression models (Case Study: Nahavand), Journal of Water and Soil Science (In Press).

22. Saaty, T. L. 1996. Decision Making for Leaders, RWS Publications. Pittsburgh.

23. Shahid, S., S. Nath and J. Roy. 2000. Groundwater potential modelling in a soft rock area using a GIS. International Journal of Remote Sensing 21(9): 1919-24.

24. Shirani, K. 2017. Modelling and Assessment of Landslide Susceptibility Zonation Using Shannon's Entropy Index and Bayesian Weight of Evidence (Case Study: Sarkhoon Basin, Karoon), Journal of Water and Soil Science 21(1): 51-68.

25. Shirani, K. and A. R. Arabameri. 2015. Landslide hazard zonation using lojestic regression method (case study: Dez e Oulia basin), Journal of Water and Soil Science 19(72): 334-321.

26. Shirani, K., A. Shafiey Dastjerdi, and J. Rahnamarad 2017. Integration of Multi-Criteria Decision Matrix and Geographical Information System to Site Selection for an Underground Dam. Electronic Journal of Geotechnical Engineering (22.09) :3669-3686.

27. Süzen, M. L. and V. Doyuran. 2004. A comparison of the GIS based landslide susceptibility assessment methods: multivariate versus bivariate. Environmental Geology 45(5):665-679.

28. Thomas, J., S. Joseph, K. P. Thrivikramji and G. Abe. 2011 Morphometric analysis of the drainage system and its hydrological implications in the rain shadow regions, Kerala, India. Journal of Geographical Sciences 21(6): 10771088.

29. Vahidnia, M. H. A., A. Alesheikh and A. Alimohammadi. 2009. Hospital site selection using fuzzy AHP and derivatives. Journal of Environmental Management (90):3048-3056.

30. Yang, C. C. and B. S. Chen. 2004. Key Quality Performance Evaluation Using Fuzzy AHP, Journal of the Chinese Institute of Industrial Engineers 21(6): 543-550. 


\title{
Prioritization and Assessment of Groundwater Resources Map in Isfahan Province
}

\author{
M. Moradizadeh ${ }^{1}$ and K. Shirani ${ }^{2 *}$
}

(Received: August 27-2018 ; Accepted: April 24-2019)

\begin{abstract}
Water resources management depends on the precise assessment of water storage and access in each region, as well as environmental interactions of these resources. The man objective of this study was to delineate the potential zones of groundwater storage using FAHP. Mapping and assessment of it required maps of geomorphology, drainage, density, lineament density, slope and vegetation, which were initially prepared as the input layers in FAHP; the appropriate weights were attributed to them based on FAHP. Potential zones of ground water were classified into five classes of poor, average, good, very good and excellent. The number and density of available wells and springs in the study area dealt with the potential of the region for groundwater storage. So, ROC was used to assess the validation of results, considering spring points as signs of water resources. According to the results, classes of very good, good, average, weak, and very weak were ranked as the first to the last in terms of privilege order with an area of 37.7, 55, 40, 107, and 98.4 square kilometers, respectively.
\end{abstract}

Keywords: Prioritization, Groundwater, Weighting, AHP

1. Department of Engineering Geology, Tehran University, Tehran, Iran.

2. Department of Soil Conservation and Watershed Management Research, Isfahan Agricultural and Natural Resources, Research and Education Center, AREEO, Isfahan, Iran.

*: Corresponding Author: Email: K.Shirani@areeo.ac.ir 